\title{
AN INVESTIGATION INTO THE RELATIONSHIP BETWEEN STUDENT ACHIEVEMENT AND CURRICULUM KNOWEDGE OF SPECIAL EDUCATION CO-TEACHERS
}

A Dissertation
Presented to
The Faculty of the Graduate School
at the University of Missouri-Columbia
In Partial Fulfillment
of the Requirements for the Degree
Doctor of Education
By
KARIN MCGRATH
Dr. Paul Watkins, Dissertation Supervisor
MAY 2018




\section{THE EFFECT OF CURRICULUM MASTERY}

C Copyright by Karin Michelle McGrath 2018

All Rights Reserved 


\section{THE EFFECT OF CURRICULUM MASTERY}

The undersigned, appointed by the dean of the Graduate School, have examined the dissertation entitled

AN INVESTIGATION INTO THE RELATIONSHIP BETWEEN STUDENT

ACHIEVEMENT AND CURRICULUM KNOWEDGE OF SPECIAL EDUCATION CO-TEACHERS

Presented by Karin Michelle McGrath, a candidate for the degree of Doctor of Education and hereby certify that, in their opinion, it is worthy of acceptance.

Dr. Paul Watkins

Dr. David Stader

Dr. Lisa Bertrand

Dr. Margaret Dalton 
THE EFFECT OF CURRICULUM MASTERY

\section{DEDICATION}

To Madelyn,

and all of my nieces and nephews, for whom the cause of making the world a better place is, and will always be, worth the investment.

also

To my Mom and Dad,

for their unwavering and immeasurable love and support. I am grateful for their care, dedication, guidance, belief, humor, and friendship.

To my sisters,

with whom, from whom, and because of, I have experienced and learned so much, especially things which cannot be communicated with words, yet remain most important.

To my Grandmother,

for her unconditional love, prayer, and sincerely always having my best interest at heart.

To Michael Thomas,

my most recent cheerleader along this journey, partner in our new normal, and with whom I will continue to learn 


\section{ACKNOWLEDGEMENTS}

I would like to acknowledge and thank both family and friends for support, encouragement, interest, even if sometimes feigned, and belief, along with all who have influenced, prior to and during this process.

My classmates, and many friends gained along this journey: those of Mizzou ELPA Co-Hort 8, with whom I discussed, wrote, struggled, drank, mused, complained, laughed, grew, and learned with, most significantly those of our MAC site original foursome, who along with Dr. Watkins, will forever form the essential and wonderful fiber of this work and experience. These professionals have both my appreciation and respect and will forever remain etched in my memory and on my heart.

My most sincere gratitude and acknowledgement is reserved for Dr. Paul Watkins; without his support, wise teaching, encouragement, guidance, patience, and assistance, this is something I simply could not have accomplished. I remain always grateful. 


\section{TABLE OF CONTENTS}

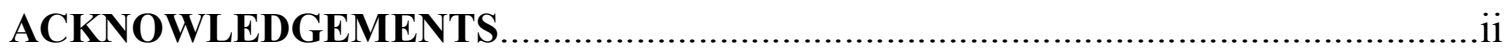

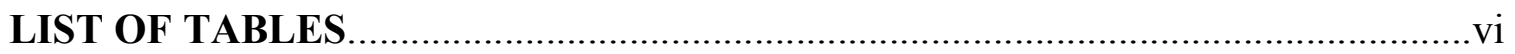

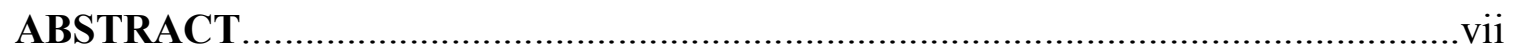

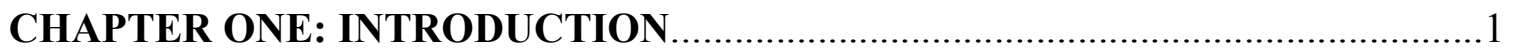

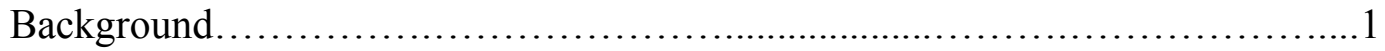

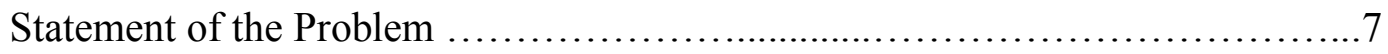

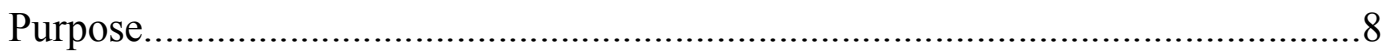

Research Questions.....................................................8

Hypotheses.............................................................. 9

Conceptual Underpinnings............................................... 10

Design and Methods.........................................................11

Limitations Assumptions and Design Control................................................13

Definition of Key Terms............................................... 15

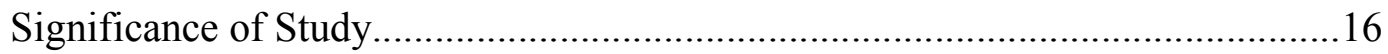

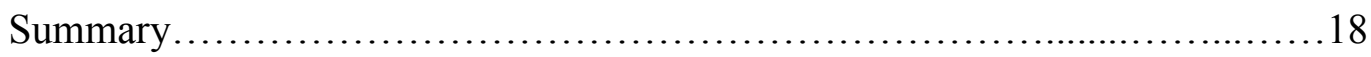

CHAPTER TWO: REVIEW OF RELATED LITERATURE ...................22

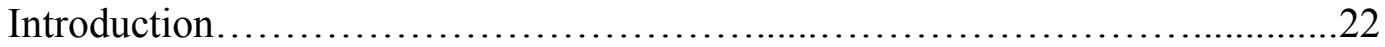

Brief Background of Special Education..................................23

Legal Milestones....................................................... 25

Special Education Environments P.L. 94-142; IDEA and beyond.................27

Effects on the Expectations and Roles of Special Educators....................34 
CHAPTER THREE: RESEARCH DESIGN AND METHODS $\ldots \ldots \ldots \ldots \ldots \ldots \ldots . \ldots . \ldots$

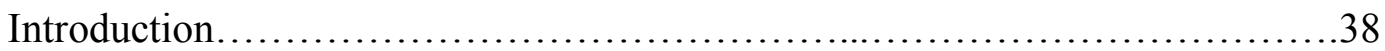

Purpose..........................................................41

Research Questions................................................42

Hypotheses.....................................................43

Participants and Sampling Procedures......................................44

Design for the Study ...............................................46

Data Collection and Instrumentation......................................................49

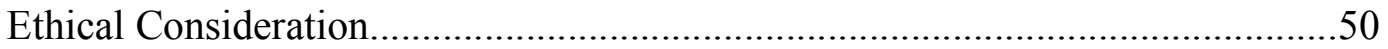

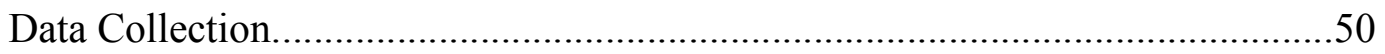

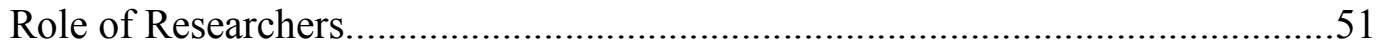

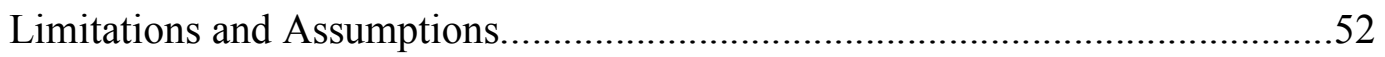

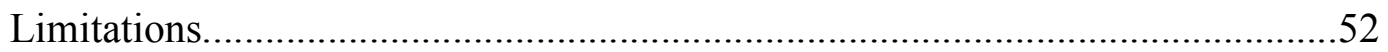

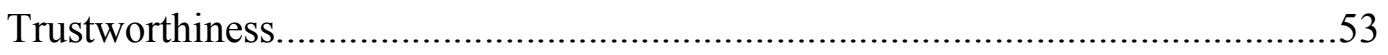

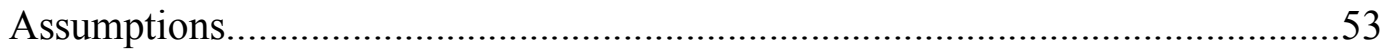

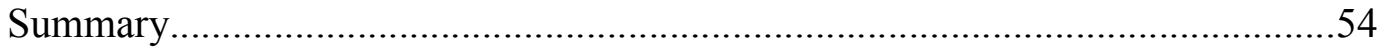

CHAPTER FOUR: RESULTS AND ANALYSIS OF DATA ..............................56

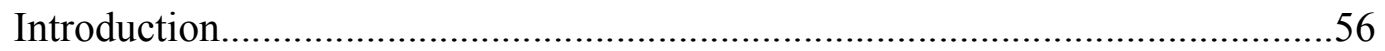

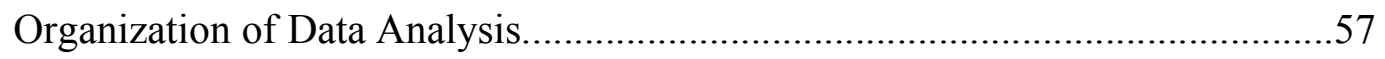

Descriptive Characteristics of Participants.....................................................58

Research Questions and associated Hypotheses............................................60

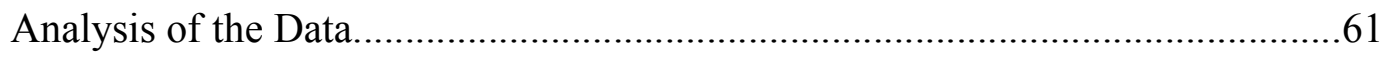

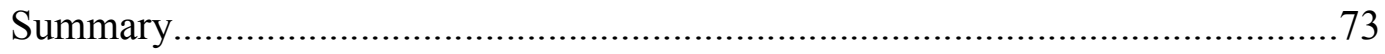


CHAPTER FIVE: FINDINGS CONCLUSIONS AND IMPLICATIONS................75

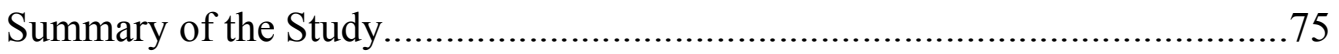

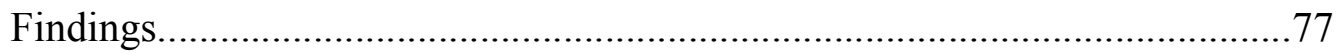

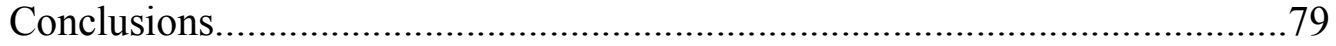

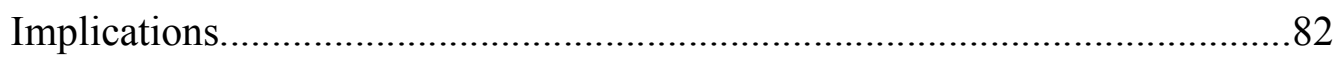

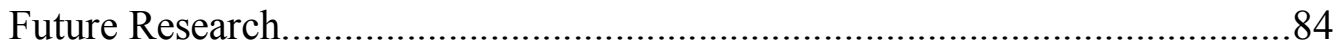

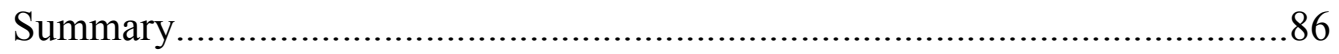

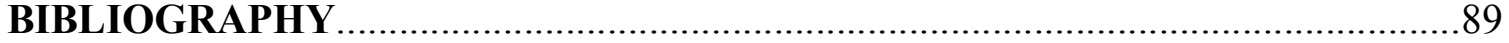

VITA A 


\section{LIST OF TABLES}

Table 1: Mean and standard deviation of student sample populations

Table 2: Mean and standard deviation of EOC scores of students in the first set of defined classroom environments.

Table 3: Results of Levene's test and t-test for EOC scores of students in the first set of defined classroom environments

Table 4: Mean and standard deviation of EOC scores of students in the first set of defined classroom environments.

Table 5: Results of Levene's test and t-test for EOC scores of students in the second set of defined classroom environments

Table 6: Mean and standard deviation of EOC scores of students in the first set of defined classroom environments.

Table 7: Results of Levene's test and t-test for EOC scores of students in the third set of defined classroom environments.....

Table 8: Mean and standard deviation of EOC scores of students in the first set of defined classroom environments.

Table 9: Results of Levene's test and t-test for EOC scores of students In the fourth set of defined classroom environments.

Table 10: Mean and standard deviation of student sample populations. 78 


\title{
AN INVESTIGATION INTO THE RELATIONSHIP BETWEEN STUDENT \\ ACHIEVEMENT AND CURRICULUM KNOWEDGE OF SPECIAL EDUCATION \\ CO-TEACHERS \\ Karin McGrath \\ Dr. Paul Watkins, Dissertation Supervisor
}

\begin{abstract}
The balance of awareness of student disabilities, providing supports and accommodations necessary for the success of special education students, and a high understanding curriculum contents is a challenge for special educators in the co-taught setting. This study investigates the effect the relationship between the number of curricula in which the special educator is co-teaching has, on student achievement. Statistical analysis was conducted to compare both the results on state mandated end of course examinations, and course grades in classrooms where the special education coteacher was responsible for one curriculum content where they were responsible for two and three curricula. Findings show a significant difference in student achievement only between classrooms where the special educator was responsible for one curriculum and where they were responsible for two. In looking at the mean achievement results for end of course examinations and course grades, students in the classrooms where the special educator was responsible for three curriculum contents earned higher scores. Results indicate that factors or a combination of factors, other than curricula content knowledge of the special education co-teacher, play a greater role in effecting the achievement of the special education students in the co-taught classroom.
\end{abstract}

Keywords: Special Education, Co-taught Classroom, Co-teaching, Curriculum 


\section{CHAPTER ONE: INTRODUCTION}

\section{Background}

Special Education, a faction of public education provides supports for students with a disability determined as having an impact on their education. This determination is made by a team of school personnel, the students' family, and the student - when applicable, and others with an investment or involvement in the student. The 1990 Americans with Disabilities Act (ADA) and 2004 Individuals with Disabilities Education Act (IDEA) ensures that schools provide students with disabilities access to a free and appropriate education (FAPE), that takes into consideration and provides necessary support or accommodations. An outcome of these acts is that school districts provide planning, attention, and resources to ensuring equity for students with disabilities. Prior to IDEA, many children with disabilities were not receiving opportunities for education that provided necessary supports for their learning. Families were not involved or supported in determining access to and involvement in public education. Many children were simply left completely out of access to and benefits of public education (U.S. Department of Education, 2007, Pullium \& Van Paten 2006).

Students with disabilities are no longer simply left out, or seen as uneducable in institutions of public education. In classrooms, struggling students may require additional resources, even while schools grapple to prioritize and disseminate what is available. Children may qualify for special education services, within public education, based on criteria including learning disabilities, physical handicaps or other needs. Over the years, laws have changed and legislation exists to protect the right to an education for these children. Outcomes for many students with disabilities were often unsatisfactory, 
through the eighties and early nineties. Steps have been seen in federal and state law and policy as attempts to address this. Services for these students may be provided through a variety of service placement models. IDEA regulation section 300.115, Continuum of Placements, explains that public agencies are to provide placements to provide for children with disabilities, and placements must include those listed under section 300.38 . These placements include the regular or general education classroom, special schools, instruction in homes, hospitals, or institutions. The section also mandates and further outlines provision for supplementary services. A spectrum of service models by which special education supports are provided ensures the avoidance of a one size fits all approach to the education of children with disabilities (Individuals with Disabilities in Education Act, 2004 McLaughlin \& Rhim, 2007). The enactment of No Child Left Behind (NCLB) includes special education students with the general population, to be evaluated with assessments at the state and district levels, based on state standards (NCLB, 2001/2002). State Standards in Missouri, identified as the "Show-Me Standards", were adopted in 1996, with Grade Level Expectations (GLE's) developed in 2001 to assist in providing districts more detail on the standards. In 2008, high school levels GLE's were grouped into Course Level Expectations (CLE's). When the standards were adopted, Missouri also worked to adopt the Missouri Assessment Program (MAP) assessments, which assesses progress toward the state standards. The MAP In the spring of 1998 the first MAP assessments were administered. These assessments were eventually utilized to meet NCLB assessment requirements. In 2008/2009, content area MAP assessments were changed to End of Course (EOC) examinations, that are taken upon completion of instruction on learning standards, regardless of the grade level. 
Beginning in 2014-2015, students must complete EOC's in Algebra I, English II, Biology, and Government prior to graduation (Missouri Department of Education, 2015, Missouri Department of Education, 2017).

As challenges with NCLB were discovered, Every Child Succeeds Act (ESSA) was enacted in 2015 to amend the Elementary and Secondary Act of 1965. (US Department of Education, 2017). With new legislation, states must make adjustments or updates to current practices. In Missouri, the department of education explained they do not anticipate significant changes due to ESSA, and that the act aligns with the MAP assessments that are in place. In addition to the ESSA and NCLB mandates for assessments at the state level, the Individuals with Disabilities Education Act reauthorizes, and includes a (Council for Exceptional Children [CEC], 2004) mandate that special education teachers be highly qualified. While there is some interpretation to this, as IDEA amendments aimed to comply with NCLB expectations, it includes special education general criteria, as well as for special educators teaching core content areas (U. S. Department of Education, 2007). The merging of IDEA and ESSA legislation will become a component of the changes school districts must work through. In the meantime, special education co-teachers are working to maintain a strong knowledge base of the curriculum contents for which they are responsible. Working with a general education teacher as a co-teaching team in the general education classroom, provides a solution beyond having every special education teacher who teaches more than one subject become certified in multiple core content areas. When special educators are coteaching, it is assumed they are also collaborating with a highly-qualified teacher in the classrooms where they teach. IDEA, NCLB, and the CEC encourage that general 
education and special education teachers work in collaboration to best meet the needs of their shared students (Individuals with Disabilities in Education Act, 2004; No Child Left Behind, 2002).

Various legislative expectations, at the federal and state level, have changed or begun, just in the past twenty-five years. As with many growth spurts there are growing pains. Public education agencies are expected to provide special education services along the continuum, and within the least restrictive environment (LRE), which indicates the setting in which students with disabilities will receive their education. The provision of support systems that are flexible and encompass a wide variety of support is a challenging, multi-faceted, and important task (Rayner, 2007, Theoharis, 2010). The LRE is typically expected to be a location where students receiving special education services have the same access to the curriculum and benefits of the general education classroom as typically developing peers, to the greatest extent possible.

Information relating to the LRE is found throughout regulations in areas such as, the 1997 amendments to IDEA, Section 1412(a)(5)(A), and Title 34 of the Code of Federal Regulations, Section 300.550(b)(1)(2). While placement decisions are predominantly left to local schools and the Individualized Education Plan (IEP) teams for each student, the US Department of Education has indicated a strong preference that appropriate supports and assistance be provided with in the general classroom setting (Individuals with Disabilities in Education Act [IDEA], 2004., U.S. Department of Education, 1994). Additionally, litigation has indicated the expectation that the general or regular education setting placement be utilized as a first option. In P.A.R.C v. Pennsylvania, conclusions included and supported that among options available within 
statutes to be available, placement for students, in a regular school classroom is preferable over special education classrooms (P.A.R.C. v. Pennsylvania, 1972). School districts, while meeting state and federal requirements, are expected to develop methods of meeting the needs of their individual student populations (U.S. Department of Education, 2007, Wishnowski, Salmon, \& Eaton, 2004).

In many settings, the general education classroom is considered the LRE, and utilizing a co-teaching model provides for the needs of the special education students. In a co-teaching classroom, the general education and special education teachers collaborate to provide instruction to those students with a disability and those without, by providing accommodations or modifications, as needed for those receiving special education services (Friend, 2008). This service model allows special education full access to the general education setting and curriculum with necessary supports for their success (Friend, Cook, Hurley-Chamberlain, Shaberger, 2010; Murawski \& Swanson, 2001).

The balance of awareness of student disabilities, providing supports and accommodations necessary for the success of special education students, and having an in depth understanding of high school curriculum contents is a challenge special education teachers must navigate. While special educators are a resource to many school personnel, they are a unique resource for general education teachers. With the opportunity to work with general education teachers, special education teachers access students requiring special education services, and provide them in the general education setting. When providing services within the co-teaching environment, special educators work with their content area peers closely. Implementation of co-teaching has increased over the past several years, and as general and special education teachers collaborate, provides an 
alternative to previously seen restrictive environments for students with disabilities (Walsh, 2011). This allows students with disabilities to participate and engage with the same curriculums, and in the same environments, as non-disabled peers (Cook \& Friend 1995, Friend, 2008).

In schools, after participating on diagnostic and IEP teams to determine the method(s) of providing the supports students need, and arranging them within student schedules, it is also expected that the teachers possess an expertise in the areas they are responsible to teach. Expectations of demonstrated expertise in assessment, procedures and policies within a school or district, procedures and policies with a legal foundation and have specialized knowledge about disabilities. As there are increased expectations for placement of students with disabilities in general education settings, and collaboration between general and special educator's increases, an awareness is needed regarding the levels of specialization and knowledge that may be unique to the field of special education (Eshilian, Falvey, Bove, Hibbard, Laiblin, Miller, \& Rosenberg, 2000). Those educators working in the area of special education strive to be aware of and support the individualized needs of their students, and grasp a thorough understanding of the curriculum content. In secondary schools, teacher certification is earned in specified content areas, while special education is its own, separate certification (Pearson Inc., 2016; 2U Inc., 2016). In the high school setting, this special education certification may lead to the question of how to best ensure special educators gain the content knowledge necessary, while managing all other special education responsibilities, to support the learning of the students they teach. Requirements for special education teachers are varied to ensure they are viewed as highly qualified for the content and setting in which they teach (Boser, 2009). 


\section{Statement of the Problem}

Special Education teachers at the secondary levels often find themselves providing services in a variety of content areas. In many public high schools, the day is typically divided into class periods, with students traveling to each class. Depending on the settings in which they are scheduled to teach, requirements for special education teachers to be considered highly qualified may vary (Boser, 2009). Generally, teacher certification areas are varied and numerous, indicative of expectations of teacher knowledge in their area of certification (Pearson Inc., 2016, 2U Inc., 2016). The coteaching environment often serves as the least restrictive environment in which special education services are provided. In these situations, the special educator is faced with managing special education responsibilities for the students in the classroom, serving as a resource to their general education co-teacher, and gaining a foundation of knowledge of the content area itself. Special education co-teachers are striving to focus on instruction and design lesson plans with general education teachers. With a wide range of knowledge needed to support students diagnosed with a disability that impacts their learning, in addition to expertise on how these diagnoses manifest in classrooms, and collaboration skills, special education co-teachers, may be expected to support students in multiple course curriculums achieve at their highest levels, and perform to district and state standards. Amendments to IDEA 2004 represent expectations that special educators are knowledgeable and skilled in the general education core curriculum standards in which they may teach (U.S. Department of Education, 2007). These circumstances place special education teachers working collaboratively with general education content area 
teachers, in positions where they need be not only well-versed in the many facets and needs of special education students, but also content curriculum standards, design, and materials.

\section{Purpose}

The intent of this study is to look at and compare achievement for those students receiving special education services in co-taught classrooms when the special education co-teacher is assigned responsibility for one curriculum content to those in co-taught classrooms, where the special education co-teacher is assigned responsibility for two or three curriculum content areas within the same school year. The literature review and conclusions from the data will explore the relationship of student achievement with the content area knowledge expectations placed upon the special education co-teacher.

\section{Research Questions}

The research questions guiding this study are:

- Will special education students score higher on end-of-course exams when in classrooms with special education co-teachers responsible for one curriculum content than those students in classrooms with special education teachers responsible for two curriculum contents in that school year?

- Will special education students score higher on end-of-course exams when in classrooms with special education co-teachers responsible for one curriculum content than those students in classrooms with special education teachers responsible for three curriculum contents in that school year? 
- Will special education students earn higher final summative class grades when in classrooms with special education co-teachers responsible for one curriculum content than those students in classrooms with special education responsible for two curriculum contents in that school year?

- Will special education students earn higher final summative class grades when in classrooms with special education co-teachers responsible for one curriculum content than those students in classrooms with special education teachers responsible for two curriculum contents in that school year?

\section{Hypothesis}

- There will be no difference in scores on EOC's in those classes with a special education co-teacher responsible for one course curriculum than those in classes with a special education teacher working responsible for two content area curricula in that school year.

- There will be no difference in scores on EOC's in those classes with a special education co-teacher responsible for one course curriculum than those in classes with a special education teacher responsible for three content area curricula in that school year.

- There will be no difference in final summative class grades for special education students in those classes with a special education co-teacher responsible for one course curriculum than those in classes with a special education teacher responsible for two content area curricula in that school year. 
- There will be no difference in final summative class grades for special education students in those classes with a special education co-teacher responsible for one course curriculum than those in classes with a special education teacher responsible for two content area curricula in that school year.

\section{Conceptual Underpinnings for the Study}

There a wide variety of factors influencing the continuum of special education services provided within high schools. Current law requires schools to provide a continuum of services that include a variety of settings, models, and methods for the provision of these services. Institutions of public education are faced with meeting federal and state legislative requirements (Walsh, 2011; Murawski, Swanson, 2001). Inclusion of students with disabilities in the general education classroom ensures their access to FAPE (Free and appropriate education) provided within the distribution of provisions to all members of society. Previously, students with disabilities were not always provided this opportunity. The theory of social justice provides a basis for inclusive education, where students with disabilities are included alongside students without disabilities. John Rawls social justice theory provides a framework for inclusive education. Within this framework is support for inclusive education as a service model that meets the specific needs of students with disabilities, while still adhering to education law. The social justice theory includes a claim for equal or fair distribution of advantages and provisions in society. Members of a society, are then in agreement that the distribution of advantages and provisions is be among the duties and protected rights of all members (Internet Encyclopedia of Philosophy, n. d.; John Rawls - Theory, n. d.). 
Meeting the need individuals have for fairness or justice is of importance in many areas. Ideally, social justice requires the establishment of institutional and other structural conditions for promoting self-determination and self-development of all members of society (Young 2000). Maslow's hierarchy of needs includes sets of goals that motivate individuals. Among these are safety and esteem, which encompass, predictability and fairness, and how one views themselves respectively. Providing students with disabilities educational opportunities within the general education setting helps ensure these needs are met, as they are for typically developing peers, increasing the likelihood of their motivation and success (Maslow, 1943).

Rawls' (1971) theory includes the idea of resources being provided in direct ratio to need. As access to the general education setting and curriculums is provided to all, it is a resource identified as one that is distributed fairly. The co-teaching model, in which access to that same general education setting and curriculum ensures inclusion of students with disabilities, it is theoretically supported by social justice thinking. Ensuring students with disabilities have access the general education curriculum allows meets the criteria for a fair distribution of advantages and provisions, the model of co-teaching provides for an increase of resources in proportion to the increase of needs the student brings into the classroom (Topping \& Maloney, 2005).

\section{Design and Methods}

This quantitative, experimental design study will utilize an inferential research approach. The design will allow for an examination of data that will reflect student achievement in relation to the assignment of special education co-teachers. Inferential 
statistics for analyzing data is a good choice when anticipating the use of the data from the utilized sample for application to a general population. In this research, the findings from the sample data will provide information regarding the potential achievement of the general population of students receiving special education services in co-taught classroom environments, and the curriculum responsibility expectations placed upon the special education co-teachers in those classrooms. Both general education and special education teachers of students from which data will be utilized have been teaching 5 or more years, and teaching together for at least 3 . Therefore, the information may be used to help inform and guide decisions regarding the scheduling and professional development of special educators (Lehman, O’Rourke, Hatcher, Stepanski, 2013, Trochim, 2006).

Individual independent T-tests will be conducted for each of the research questions. T-tests will provide insight to conclude if the difference between the means of two samples significantly different enough to say that some other characteristic could have effected that difference (Biddix, 2009). Student performance, based on their end of course exam results and state mandated end of course examinations, allow for comparison of student achievement. Student achievement scores will be measured utilizing their grade earned in the class, and score on the state end-of-course exam in three courses, all requiring an EOC state assessment. The achievement data from three different special education teachers will be used in the research, each responsible for one course that includes an EOC. One teacher is responsible for the curriculum of only that course, the second is responsible for that course plus one more curriculum content, and the third, for that course, plus two more curriculum contents. Student data from building 
records will be tabulated and used for analysis. For this research, the independent variable of the number of curriculums for which a special education co-teacher is responsible will include three categories. First, the special education co-teacher is responsible for only one curriculum, the second, when they are responsible for two, and the third, responsible for three. The dependent variable of student achievement will include the measurement of end of year, summative course grade, and score earned on the EOC state assessment.

It is the anticipation that the research findings will include a significant difference in the student achievement, correlated to the number of curriculums for which the special education co-teacher is responsible. If found, additional statistical analysis can be performed to further detect which independent variable categories are related to the differences between the dependent variables. This information can provide implications to inform decisions related to the continuum of services provided, and the scheduling of special education teachers within content areas at the high school level.

\section{Limitations, Assumptions, and Design Controls}

The researcher worked as a special education co-teacher within the building, during the period of data collection. To protect from bias, data from the classes in which she taught were not used as part of the analyzation for this study. Student information will be assigned numbers for anonymity, as opposed to utilization of student names. Data collection will include grades (by percentile) of students at the end of each semester, as well as on their EOC exams at the end of the school year, (dates determined annually by the state). Class grades are administered with the general education co-teacher, and EOC 
scores are provided from state assessment teams. The special education teacher is not the source of scores in these classrooms. This quantitative study will utilize a use of a population of convenience. The population utilized will represent students in different courses. The course circumstance, and student participants are within the school where the researcher is employed, though not among students she teaches.

In ensuring validity, data will be used from one school year for each course: Government, English II and Biology. Represented school years will include 2010/2011, 2011/2012. Data on student achievement will be analyzed using both students final grade for the course, and their performance on state end of course exams in the three scenarios listed above using t-tests for statistical analysis.

Assumptions made by the researcher include: (a) the role of the researcher will not inhibit grades earned by students in either of the courses, or their performance on state assessments, (b) the specific roles of the special education co-teacher will not inhibit or influence the grade or EOC score, (c) students have been enrolled and engaged in a coteaching classroom, will receive a percentage grade, and will participate in the state EOC test for that course, on which they will also receive a percentage grade as measurement, (d) the co-teaching relationships within the three courses are positive and reasonably mature relationships.

Research will take place in a Midwestern rural high school, where the researcher is employed. The population is one of convenience, though it uses any enrolled student, receiving special education support, in co-taught classrooms that require an EOC test at the completion of the course. The data from this group of students presents a random sampling from the population of special education student achievement data used for this 
study. Class grade and EOC score information will be collected anonymously. Additionally, it will be communicated that the purpose of all data collected is for the purpose of this researcher. Research was limited to one Midwestern rural high school, with approximately 130 teaching staff and 1900 students. Student data from the courses Biology, English II, and Government, will be utilized. These courses were selected due to the requirement of an end-of-course exam. With the intention of the research examining its effect on student achievement, the variable of number of curricula assigned to a special education co-teacher was controlled. Variables such as demographics, gender, class size, and teacher experience and quality may play a role in results. The use of the course grade and EOC score provides two measures of student achievement.

Three specific special education co-teachers have taught the courses utilized for at least three years prior to this study. The data was limited to courses that include an EOC as mandated by the state of Missouri. Student data and statistical analysis findings can be generalized to these or other co-taught courses as well as special education co-teachers, and general education co-teachers, for other courses, as well as in schools of similar demographic or socio-economic situations.

\section{Definition of Key Terms}

The following definitions are basic to this study:

Classroom Environment: This refers to the design of the classroom such as seating arrangements, where the teacher stands during class, and general aesthetic look of the room. 
Co-teaching: A model in which special education services are provided in a classroom taught by a collaborative team of a general education teacher, and special education teacher. Students receiving special education services and not receiving special education teachers are shared by both teachers in the classroom EOC: End of Course Exam - state assessments mandated for Graduation by the state of Missouri in Algebra I, Biology, English II, and Government courses. The High School course component of the Missouri Assessment Program (MAP) Inclusion/Mainstreaming: bringing special education students into the general education environment to receive services needed rather than providing those services in separate rooms, or keeping special education students isolated from the general population on an ongoing basis

Least Restrictive Environment: An educational setting, in which children with disabilities, with supports in place to meet their needs, are to the greatest extent possible, accessing curriculums and day to day school events, in the general education setting with typically developing, peers of similar age or grade.

Special Education Students: Those students with a disability identified as having a significant impact on their education, therefore requiring supports beyond the scope of what is available only through general education provisions.

\section{Significance of the Study}

The influence that the special educator's knowledge of content area curriculum in the classes they co-teach has on the achievement of students receiving special education services in those classes warrants attention. It is worth the time and energy of those 
planning to consider the expectations and burdens put upon special education teachers and their relationship to student achievement. With the responsibility, a special education teacher has, of the content area curriculum in which they teach, so they are able to accommodate work and assessments, according to needs that arise from various disabilities, it is beneficial to consider the number of curriculums for which they are responsible as co-teachers. An awareness of the relationship between student achievement and the number of curriculum content areas for which a special education co-teacher is responsible, at the high school level, is worth time and energy of those planning for high school special education services. Students with a wide breadth of disabilities and needs are participating and accessing their educational content in the general education setting. Investigating where the threshold lines fall between expectations of curriculum content knowledge, in combination with already existing special education responsibilities and the ability to maintain quality teaching performance for special education co-teachers is important.

Implications of the research may be related to areas of building scheduling, professional development for special educators and general educators, IEP accommodations provided within the co-teaching environments, and the roles and expectations of both special educators and general educators in co-taught classrooms. Outcomes of this study will also be of interest to parents of students receiving special education services, specifically as they participate in IEP meetings and planning for the educational environment in which their child will best be supported and learn. Analysis of the data will provide information regarding the difference in student achievement measured both by class grade and EOC scores. When analyzed, if those differences are 
determined significant, further statistical analysis is anticipated. Additional analysis will answer more questions, and provide further information on which situations faced by special education and general education co-teachers or other key stake-holders, influence those discovered differences. Research findings may also provide information that will highlight areas in which schools can focus on processes by which students are placed in learning environments with special education services and improving provision of special education services in co-taught settings. These areas may include adjusting professional development time, specific professional development learning opportunities, planning time for co-teachers both separately and together, or professional development for all building staff on the purposes and desired outcomes of co-taught classrooms. The support of the knowledge base of special education co-teachers, scheduling practices to provide co-teaching teams opportunities for shared planning and communication, and increased awareness, related to the co-taught setting, of all building staff can better support both general education and special education co-teachers and their shared students receiving the special education services that are provided through the co-taught setting.

\section{Summary}

Throughout the United States, schools are struggling to meet the growing needs of students with a decreasing pool of resources. Individuals of many demographic backgrounds have an opinion of how schools should work - what they should or shouldn't do to ensure children and young adults are learning. Many are under the belief that because they have been a student themselves, they are fully aware of how schools 
should operate and how all students learn best. School districts grapple with how to support curious, enthusiastic, quick-learning children, alongside less motivated, less able, or struggling peers. Students enter schools with a range of experiences, supports, and resources available to them. Districts seek out new instructional strategies, technologies, curriculums and materials to better support the success of their students. While collaboration among special education teachers and general education teachers has increased, therefore improving inclusion of students with disabilities in general education environments, educators - both general education and special education - continue to strive to find ways to cultivate circumstances in which all children achieve and succeed. Content knowledge of special educators at the secondary level often varies. In high schools, a teacher is typically identified as a specific content area teacher. Special education teachers, hold certification in special education, with a range of background knowledge of the course content for specialized certifications at the high school level. Striving for the optimal amount of expectations and support for special educators working as co-teachers is important to co-teaching classroom environment, and student learning. Teaching in Missouri at any level, requires certification. Missouri's Department of Elementary and Secondary Education (DESE) explains that an initial professional certificate (IPC) is the first a new educator receives. A baccalaureate degree, with a minimum of a 2.5 grade point average, from an institution with an approved teacher education program is required, along with passing scores on state required teacher certification assessments. (Pearson Inc., 2016, 2U, Inc., 2016) Ensuring special education teachers, specifically those that are placed in co-teaching classroom 
situations, have a foundation and understanding of the course curriculum is important to their role in both teaching and accommodating for students.

This research study will look at co-teaching environments, in which special education teachers collaborate with general education teachers for three of the four classes identified by the state of Missouri to require an end of course state examination. Within the setting of the high school used in this study, these classes are: Algebra I, Biology, and English II. An analysis of data from scenarios where the number of curricula in which the special education co-teacher is teamed with a general education coteacher is set at one, two, and three, using Levene's test for equality of variance, t-tests comparing mean achievement scores, and Cohen's $d$, measuring effect size, will be conducted. The investigation will include achievement of students receiving special education services in the co-taught settings. The comparison will be of means of the achievement data from the classes where the special education co-teacher is responsible for one curriculum content, and where they are responsible for two curricula, and again where they are responsible for three curricula.

Findings and conclusions from this research may provide teachers and administration involved with special education important information regarding the success of students receiving special education services. Careful consideration should be given to expectations on special education co-teachers. When there is a need to become familiar with originally unfamiliar wide varieties of content area curriculum, the effect those expectations have on the general education teachers with whom they collaborate, and the students in those classrooms require consideration. Considerable planning regarding practices for arranging models by which special education services are 
provided in high school settings is necessary. Awareness of expectations on special education co-teachers to be familiar with wide varieties of content areas, and its relationship with student achievement is a simple first step. With more awareness of the relationship between curriculum expectations on special education co-teachers, this consideration and planning can be more informed and intentional, to better support student achievement and success. 


\section{CHAPTER 2: REVIEW OF RELATED LITERATURE}

\section{Introduction}

This chapter provides an overview of the background of Special Education services in public education. Beginnings of education opportunities and expectations for children with physical, mental, and emotional disabilities included labels of un-educable and no opportunities related to education at all. Realizations of the importance of recognizing abilities, even when different, and the value of the social justice of including all children in education have occurred, even if slowly. Movements began toward allowing and creating supportive situations. Opportunities where students with disabilities received some form of assistance or minimal education, or those where children with learning differences would be allowed in same education buildings as same age peers, even though they were often entirely separated from interaction or common experiences, began to emerge. Progression of this education movement, focusing on differently able students, toward mainstreaming and inclusion for students receiving special education services, and into the co-teaching method of providing these services is discussed. General expectations, societal responses, and eventual components of legal actions or rights of students relating to education access play a part in the history of special education. Through the history of schools and education overall, provision of special education services, the development of the co-teaching environment began, and has evolved. It is now often seen as a common delivery method of special education services in a general education setting. The roles and expectations of the general education co-teacher and special education co-teacher partnership in co-taught classrooms are essential, influencing factors on the success of this educational 
environment. The knowledge base needed by special education co-teachers, as they collaborate with general education co- teachers, and share the responsibility for teaching curriculum content is important to consider, and is increasing.

\section{A Brief Background of Special Education}

Historically children with disabilities or 'something wrong with them' were ignored in society. Parents, doctors, teachers, lawmakers, and community members simply did not have the resources, knowledge, interest or motivation to carefully identify what the problem may be or explore the potential of these children (Martin, E. Martin, R., \& Terman, D. 1996, Pullium \& Van Paten 2006). Over time the education system has gone through many changes. Despite compulsory education laws, mandating school attendance, that have been in place since 1918, many disabled or special needs children were excluded from schools. School aged children with special needs remained at home or were institutionalized. Those with mild or moderate disabilities, despite enrolling, would commonly drop out before graduation from high school. (Pardini, 2002) State institutions were often persons with significant disabilities. Many of these restrictive settings provided only minimal food, clothing, and shelter (U.S. Department of Education, 2007). Learning disabilities or problems that children faced were only lightly addressed; the family doctor was more or less the one to provide the small amount of services available. “...special education embraced the diagnostic/prescriptive model characteristic of modern medicine, and disability was viewed as pathology. Psychology, with its partner the test industry, became the 'gatekeeper' for special education" (Sailor \& Roger 2005, p 504). Additionally, work and thought in fields including medicine, 
psychiatry, and psychology contributed much of the knowledge and theory in special education. (Barnes, Mercer \& Shakespeare, 1999) Some research states that this mentality is apparent in special education today, while it may not be recognized many professionals in the field of education have traditionally work from a model of disability based medical models (Zaretsky, 2005). Zaretsky also proposes that theories about special education and the provision of special education services are an integral part of the existing and continual problems facing educators as educators and education system try to service students appropriately. The article states that educational professionals rely heavily on the medical knowledge base as it is considered stable, objective and helpful as decisions are made about programs and placements for students. The author also acknowledges contributions from the fields of science and medicine to developing what is known, and is used in research relating to both learning and teaching (Zaretsky, 2005).

Historical events such as the Civil Rights Movement affected education laws, and began to shine light on the inequalities of our education system. The 1954 Brown $v$. Board of Education case extending equal protection under the law to minorities paved the way for these types of educational gains for individuals with disabilities (Pardini, 2002, Esteves \& Rao, 2008). Additional forward motion was made legally through the 1950s and 1960s. With the support of family associations, such as the Association for Retarded Citizens (ARC, ) the federal government began developing practices for these families and children with disabilities. The foundation for special education and programs and services for early intervention was laid from the implementation of these practices. The expectations for school districts to provide a free and appropriate education, within the outlined processes are predominantly explained through what is known today as IDEA 
2004 (Individual with Disabilities Act 2004; Martin, E. Martin, R., \& Terman, D. 1996;

U.S. Department of Education, 2007).

\section{Legal Milestones}

Movement continued through the 1960s as advocates pushed for Federal involvement in the funding as well as the leadership for efforts toward the provision of a free appropriate education, or FAPE, for disabled children. Early federal litigation demonstrated progress in providing services to children with special needs. The Training of Professional Personnel Act of 1959, P.L. 86-158, helped train those educating children with mental retardation, The Captioned Film Acts of 1958, P.L. 85-905, supporting accessible films and the Teachers of the Deaf Act of 1961, P.L. 87-276 which trained personnel for children with hearing difficulties or deafness. (Twenty-five years, n.d.) The country as a whole was making changes in its education system. In 1996, under Title VI of the Elementary and Secondary Schools Act (ESEA), congress established the Bureau for Education of the Handicapped. (Council for, 2003) Additional movement toward serving children with disabilities continued as parents pursued state laws to require educational institutions to offer services to children with disabilities and special needs. Many major milestones were reached in the 1960s. By 1968, training for more than 30,000 teachers and related professionals in special education had been provided, more than 3 million captioned films had been viewed by persons who were deaf, and State operated schools offered various education services for children with disabilities in preschools, elementary schools, and high schools across the country (Twenty-five years, n.d.). The Bureau for education eventually suggested the various programs that were 
developing, and laws to support them, be brought together under a single law. The Education of the Handicapped Act, P.L. 91-230 passed in 1970 (Council for, 2003). Although the groundwork was being laid, and progress, it would seem should follow, change takes time.

Despite the passage of these laws, and some funding through P.L. 91-230, The Education of the Handicapped Act, many children remained in need of educational support, programs or services. Children with disabilities were not receiving the services they needed. As far back as the early 1970s there were 8 million children with disabilities in the United States, with one half were not receiving special education services (Council for, 2002). In addition to the actual provision of special education services other problems were arising regarding special education and the services provided to children with disabilities. Parents were not being made aware that their children were being evaluated for suspected disabilities, or given the opportunity to participate in the evaluation. Students with disabilities were often excluded by their parents from compulsory attendance regulations, and many children with disabilities who were in schools were missing out on meaningful and necessary educational services (Council for, 2002) The federal court case, Pennsylvania Association of Retarded Citizens (PARC) v Commonwealth of Pennsylvania in 1971 was monumental as it granted the right to an education for children with disabilities, and clearly expressed homebound or residential care be used in rare circumstances (Council for, 2002, Council for, 2003, P.A.R.C. v. Pennsylvania, 1972). Another court case, Mills v Board of Education of the District of Columbia in 1972, further established that it we do have an obligation to educate children with disabilities, and the right to that education is found or 
based upon the equal protection clause found in the $14^{\text {th }}$ Amendment to the United States Constitution (Twenty-five years, n.d., Council for 2003).

\section{Special Education Environments P.L. 94-142; IDEA and beyond}

Public Law 94-142 proved to be significant legislation. Congress enacted the Education for All Handicapped Children Act in 1975, this law is currently enacted as the Individuals with Disabilities Education Act (IDEA). This law requires that all children with disabilities receive a free and appropriate education (FAPE). Public schools are required to provide services for children with a broad range of disabilities such as physical handicaps, language or emotional problems (Pardini, 2002, Council, for 2002). The changes in how children with disabilities were educated began to change in larger ways. This continues even today, currently, nearly six million students receive special education and related services (Twenty-five years, n.d.).

While further defining the rights of children with disabilities, school districts were now called to provide services in the least restrictive environment (Pardini, 2002) History has shown that education has changed, and that with change, there is often controversy. In this instance there also seems to be confusion. One of the current topics drawing the attention of many educators is that of the environment within which to provide special education services. Determining what that least restrictive environment is for students continues to be a challenge for educators, parents, and others even today. One article explained that in recent years, practitioners and scholars working in the areas of special education and studying disabilities are struggling to grasp and define the 
concept of inclusion, from which a heated debate is being is created about the how practices and programs of inclusive education look and take place (Zaretsky, 2005). Inclusion and mainstreaming, which support students with disabilities or special needs being a part of a regular or general education classroom rather than pulled out or segregated for special education services, are controversial topics, although defined by many as the least restrictive environment. Research has shown various methods of trying to meet the educational needs of students with special issues, while providing the least restrictive environment. Wolf and Hall note that more students with disabilities are receiving special education services in the general education setting or least restrictive environment (LRE), promoted by the Individuals with Disabilities Act (IDEA) (Wolf, P., Hall, 2003). The concept of LRE is based on the belief that educators must provide a range of placement options (Mastropieri \& Scruggs, 2000; Thomas \& Rapport, 1998).

Additional researchers have conducted studies to highlight the viewpoints, perceptions, and theories that those most closely involved with the education of children with disabilities and the impact this may have on the process of inclusion or mainstreaming. There has been advocacy by educators, administrators, parents, and individuals with disabilities to increase inclusion of those with disabilities in the general education setting (Dunn, 1968, Will, 1986, Sailor, 2009). The desire and necessity to comply with law is inherently a part of our educational institutions, as is the desire and necessity to provide the best education possible for all students. The challenge of how this manifest, and how inclusion or the least restrictive environment are actually defined is important work of those in education (Rayner, 2007, Theoharis, 2010, Sanzo, Clayton, \& Sherman, 2011). Although society has made great strides since children with special 
needs were sent to institutions or stayed home, educators continue to struggle with how to best service children with disabilities and special needs.

The perception of parents or other significant others may also play a role in the success of inclusion for special education students. Leyser \& Kirk explain that while evidence that was presented suggests that parents were in support of or interested in inclusive education, they often communicated concerns and doubts (Leyser \& Kirk, 2004). It is impossible to determine what is best for a student's education simply by looking at the services provided or the environment within which received. Perception by mainstream teachers, parents of students who have those other teachers, and other significant adults in schools play a crucial role in how those with disabilities are accepted in general education mainstream classes (Kniveton, 2004). Legislation is also highlighting involvement from parents in the education of children with special needs. Many countries have regulations or reform acts that have produced guidelines for including active involvement of parents in the student's education. The Individuals with Disabilities Act (IDEA), in the United States includes the rights of parents to be involved in their child's referral, initial diagnostic testing, development of their individualized education plan, placement and program evaluation (Leyser \& Kirk, 2004). Although parents were typically supportive, even with hesitancy or concerns, of inclusion, an overall norm of positive feelings toward the inclusion of students with special education needs was identified. (Leyser \& Kirk, 2004) While parents recognized benefits such as social and affective outcomes many expressed concerns about emotional affects, quality of instruction, and possible loss of needed services. The study by Kniveton also showed that the majority of parents, were supportive, from both a legal and philosophical 
standpoint to the concepts of inclusion or mainstreaming. (Kniveton, 2004). Factors were also noted that were associated with parent perceptions of inclusion. Views that were more supportive were seen for parents of students with mild disabilities in comparison with those with moderate and severe disabilities, for parents of younger age children in comparison with secondary levels and for parents of children receiving services for a few years in comparison with those receiving services for five or more years. It was also stated that as inclusive education becoming a guiding policy in many countries, continued parental support and involvement is essential to its success.

Zaretsky found that a core conflict lies in the use of inclusive models not based on backing or belief in appropriate inclusive theories. The findings stated that the filter through which we are viewing special education affects how successful we are at providing for the needs of the students we are serving. The author states that the research and theories commonly associated with the initiative of full inclusion are understood by few practitioners. This unawareness often includes a lack of understanding of the reasons others may for an alternative placement range of options ranging from segregated to integrated special education settings. The need exists for those involved in education to determine the sources and evaluate views or beliefs that are may be held. Zaretsky also states that only one perspective is not enough when striving for a better understanding of what is required for knowledge and expertise in special education. It is suggested that inclusive education will only begin to be successful when an approach that includes multiple perspectives be utilized (Zaretsky, 2005). 
This research, concluding that theories of special education need to be brought forward for practitioners to truly understand the reasons inclusion is beneficial to students also found special education programs that were most successful found shared characteristics of educational leadership, involvement of parents and community, and a high level of collaboration and interaction among those involved with the education of children requiring special education services (Zaretsky, 2005).

In a special section on special education in Phi Delta Kappan, additional authors encourage education professionals to rethink inclusion (Sailor \& Roger, 2005). The article states that the fact that inclusion hasn't gained strong support from general education is partially due to the way it has been defined, beginning with the general education classroom as the unit for the provision of support. This may often seem impossible to a general education teacher whose job is typically moving students uniformly through a curriculum. Another possible way inclusion may fail is when special education students are not truly included in the components of the classroom, and may be at side or back tables working on other things (Sailor \& Roger, 2005). Concerns about these same types of interactions are supported by other research. The decisions of placement for an individual child in mainstream general education classes need to consider the fact that the perceptions of the significant others, toward children with disabilities can be very different. As it is lacking among many practitioners, effort and energy may need to be spent educating and improving understanding if the perceptions are to help the child (Kniveton, 2004, Zaretsky, 2005). Within the concept of rethinking inclusion, Sailor \& Blair identify six characteristics seen in research sites that utilized a school wide applications model to illustrate how an integrated model of special education 
works in practice. The characteristics included: General education guiding learning, with collaborative support from special educators, School resources configured to benefit all students, addressing social development and citizenship, Schools are democratically organized, data-driven, problem solving systems, Schools have open boundaries with families and communities, and Schools enjoy district support for undertaking and extensive systems-change effort.

These six characteristics, while not identical, are similar to others seen in research seeking best practices in special education. As confusion and controversy surround how to best serve students with special needs, and what placement is most appropriate, many practitioners and scholars have conducted research to identify what is working. The findings of Zaretsky, and Sailor \& Blair were consistent with the research in the ERIC/OSEP Topical Brief, To Light a Beacon: What Administrators to make Schools Successful for All Students, which highlighted research from three studies in a US Office of Special Education sponsored research series. The first study, through the University of Maryland, led by Margaret McLaughlin and Elizabeth Caron, looked at elementary and middle schools that have supported high performance for all students and education reform. The second, through the University of Minnesota and the Council for Exceptional Children, led by Teri Wallace, Tom Bartholomay, \& Christine Mason, looked at secondary schools with exemplary results for students with disabilities. The third, through the Education Development Center, Inc., led by Catherine Cobb Morocco, Cindy Aguilar, Nancy Brigham, \& Nancy Clark-Chiarelli, looked at how urban middle schools combine middle grade education with strategies for including students with disabilities. Each study focused on identifying features of exemplary learning, and 
examining how those features enhanced learning for all students including those with disabilities. Common to all three studies were several concepts: Communication $\&$ collaboration, Common goals, High expectations \& professional development for staff. Communication was in seen at many levels of the schools they highlighted; Parent to school, administration to staff, teacher to student and student to teacher. The responsibility for the communication process needs to be shared by everyone involved in the process of education. The concept of collaboration was closely tied to communication. In addition to simply verbalizing thoughts to one another, specific behaviors of individuals working together, brainstorming, and, sharing and improving on ideas while functioning as a team were all also noted. This was also listed as essential between special education staff and general education staff. Common goals for the school also helped with the sense of a team. With strong leadership, the goals were shared, and staff knew what all building staff were striving to accomplish together. Professional development and ongoing learning for teachers and building staff was evident in the schools highlighted in the study. Common traits were evident among the schools where success was seen for special education services, in some instances schools are seeking to change how inclusion is viewed altogether (ERIC/OSEP, 2002). While there are traits common to schools where success is evident in special education, many still struggle with how to truly make inclusion or mainstreaming successful for students.

Terms such as mainstreaming and inclusion float throughout schools, among parents, and among teachers as they strive to determine what is the least restrictive environment, and what is needed to demonstrate that students are in that environment, while receiving the required free and appropriate education? While mainstreaming to the 
maximum extent appropriate was enacted in the Education of All Handicapped Children Act of 1975 P.L. 94-142 it “did not 'define' the least restrictive environment, nor did it use the term mainstreaming" (Council for, 2002). Hagan-Burke \& Jefferson point out that the belief that seems to have become commonly held is that the least restrictive environment always means the general education classroom. They hold that the least restrictive environment is a set of procedures for determining the appropriate placement for a specific student, not an actual place. (Hagan-Burke \& Jefferson, 2002). A free and appropriate education within the least restrictive environment cannot occur when looking at only the location in which the education is taking place. A continuum becomes a virtual necessity to truly be in compliance, as well as meeting the needs of students (Hagan-Burke \& Jefferson, 2002, Individuals with Disabilities in Education Act [IDEA], 2004., U.S. Department of Education, 1994).

\section{Effects on the expectations and roles of special educators}

Missouri Legal Rights Advocacy Services Legal Rights Handbook from 2004 states, only when the nature and severity of a disability that an education cannot be achieved in a regular education classroom setting should special classes, separate schools, or the removal of students with disabilities from the regular classroom occur. It is expected that the IEP team will opt for student participation in regular education classrooms, when the child can be educated with services, supports or other accommodations, as opposed to removing the child and utilizing special education settings (Missouri Protection and Legal Rights, 2004). These services, supports and accommodations may include: paraphrasing, clarifying, or reading curriculum material, 
note-taking assistance, graphic organizers, repeated review of material, modified or alternative assignments or assessments, and prompts or cues for focus/attention, or behavioral needs. Based on this increasing emphasis on inclusion, when determining student placement, teams are opting for the general education classrooms with coteaching, more students with disabilities are receiving special education services in regular classrooms.

Co-taught classrooms provide an environment where students with disabilities are learning and working alongside non-disabled peers. Students in these environments interact with, learn with, and develop relationships with individuals of differing ability levels from their own. With the increased variance of ability, the co-taught team must work together to meet the needs of all students in the classroom. While this has increased the need for collaboration between general and special educators, the required wide knowledge base within the field of special education continues. "Special educators must continue to demonstrate particular expertise in assessment, procedural matters, and legal foundation and have specialized knowledge about disabilities" (Dingle, Falvey, Givner, Haager, 2004). Over half of the students receiving special education services in regular schools are in the general education setting for the majority of their school day. According to the U.S. Department of Education, National Center for Education Statistics, "In $201295 \%$ of 6- to 21-year-old students with disabilities were served in regular schools" Of those in regular schools, $61.2 \%$ were in the general education setting $80 \%$ of their day or more (US Department of Education, 2016). This is the population typically receiving services in a co taught setting and still held to standards of No Child Left Behind \& state testing accountability. The pressure on schools to include students with 
disabilities in the general education setting for curriculum instruction and assessment is increasing (Dingle, Falvey, Givner, Haager, 2004). With the increased expectation of inclusion of those with special education needs in general education classroom settings, special educators find themselves responsible for co-teaching curriculum contents in which they are not highly versed.

As models of preparing special education teachers are examined, it is being noted that it is important to consider that special educators are having to gain unique levels of specialization for the field (Eshilian, Falvey, Bove, Hibbard, Laiblin, Miller, \& Rosenberg, 2000). The question of reasonable expectations of special education and curriculum content knowledge for a special education teacher remains. Ensuring special education services, related to a student's specific disability area, are in place to produce grade level learning expectations is consistently a task for special educators. Messages from IDEA and NCLB are fundamentally that a focus of special education should be on producing results (Esteves, K. \& Roa, S., 2008). A shift in teacher education is needed for shared responsibility for student learning among general and special educators (Kozleski, Pugach, Yinger, 2002). This shift includes special education teachers increasing knowledge base to include content understanding and familiarity with the curricula for which they are responsible, as well as expertise in special education. Amendments to IDEA in 1997 lay out requirements that special educators have teaching skills, knowledge of the general education core curriculum standards and use of assessment systems so they are able to educate students with disabilities in the general education settings (Dingle, Falvey, Givener, Haager, 2004). The purpose of this study is to more closely look how, if at all, the number of curricula in which the special education 
co-teacher is teaching and providing special education services, affects the success of the special education students. One article states that, data should be what is used to guide the decisions about student placement, what will result in educational benefit, and what is the least restrictive environment for that student (Hagan-Burke, Jefferson, 2002). In congruence with this advice, data from courses in which the special education teacher is responsible for one, two, and three, curricula will be analyzed and compared. 


\section{CHAPTER THREE: RESEARCH DESIGN AND METHODOLOGY}

\section{Introduction}

Chapter one included a brief history of special education, explained the coteaching model and roles. The chapter reviewed the need for additional information relating to expectations on special education teachers in the co-teaching model of providing special education services. Finally, chapter one laid out the research questions, hypothesis and direction of the research intentions of this paper. Chapter two included a focus on current literature: reviewing the progression of special education services toward inclusion and movement into co-teaching, and the burden of the need for curriculum content knowledge placed upon special education co-teachers in the co-taught classrooms. Additionally, in discussing special education co-teacher's expertise requirements in high school classrooms, the question of how the mastery of the curriculum by special education co-teachers is related to the achievement of students receiving special education services in those classrooms arises. In this chapter, the problem and purposes of the research in this study addresses, the research questions, and related hypothesis, will be reviewed. Through chapter three, the population and sampling methods, data collection, and data analysis will be presented.

The content and curricula knowledge that is possessed by the special education co-teacher has an effect on the learning and overall achievement of students. An increased awareness relating to the extent of that effect is required to best support the needs of those students receiving special education services in co-taught classrooms. Consideration of that effect, therefore, warrants more attention. The intent of this 
research is to investigate more closely how, if at all, the number of curricula in which the special education co-teacher is teaching while developing and providing special education services, affects the success of the students receiving special education services in the co-taught classroom environment. Achievement of those students when the special education co-teacher is assigned responsibility for one curriculum content will be compared to the achievement of those students receiving services in co-taught classrooms, when the special education co-teacher is assigned responsibility for two curricula content areas, and then compared again to the student achievement when the special education co-teacher is responsible for three curriculum content areas. The comparisons of achievement will include statistical analysis

With the ever-increasing need for school improvement facing public education, schools, and teachers continue to strive to support learning and increase the achievement and success of their students. Within the overall population of public education schools, there are a percentage of students qualifying and receiving special education services. Under the Individuals with Disabilities Education Improvement Act (IDEA) of 2004 all children with disabilities are to receive the special education and related services needed for their education. These special education services are within requirements under the umbrella of receiving a free and appropriate public education (FAPE). A free and appropriate public education is expected to be provided to students enrolled in public education institutions, and measures must be in place to ensure that includes those students with disabilities.

Schools use evaluative data to measure and express student learning and achievement from various sources. Achievement and ability testing, teacher input, class 
performance, along with physical conditions, or social/behavioral scales are a few of the sources of information to determine if a disability exists, and the educational needs for students (Missouri Department of Education, 2013, Missouri Protection and Legal Rights, 2004, Missouri Legal Aid, 2006). Levels of special education services are available with many variations of levels of supports and locations for service provision. The continuum of services for students includes time inside the general education environment or outside of that environment, depending on the needs of the students. This model of a co-teaching environment, where special education needs are provided for with a special educator as a co-teacher in the general education environment, with a general education content teacher, is common. This model, where the special education teacher and general education teacher work in partnership to teach all students in a class, ensures that the students educational program is provided in the Least Restrictive Environment (LRE) (Hall \& Wolfe, 2003, Walsh, 2012).

General and special educators, along with other education professionals, want to provide an effective learning environment that is beneficial to all students. Those in the classroom strive to utilize teaching methods that facilitate student learning, that allow for the students to present successfully their classrooms. Working in tandem with another educator, when presenting curriculum material, requires that both teachers have a working knowledge of the material. A positive working partnership is important between the special educator and general educator in the co-teaching team. To this end, these teachers strive to ensure that the content knowledge is shared with the special educator, and special education knowledge is shared with the general educator (Friend \& Cook, 1990, 1996). 
Through this study, I will explore student performance, as demonstrated through both course grades and scores on state provided and mandated assessments. With IRB approval, this quantitative study will explore the relationship between the achievement of special education students in the co-taught environment when the special education teacher is responsible for only one content area curriculum, and when they are responsible for two or more. There are four courses for which state mandated end of course examinations are required for a high school diploma: Algebra I, Biology, English II, and Government (Missouri Department of Education, 2016). Three of these four courses will be reviewed and analyzed. The number of curricula content for which a special education co-teacher is responsible can encumber these individuals with expectations that hinder the greatest levels of teaching and special education support in co-taught classrooms. The need for special education teacher knowledge of content in and of itself, is an argument for fewer content areas.

\section{Purpose}

The intent of this study is to explore the relationship between student achievement and the context of teaching assignments for the special education co-teacher. As the expectation of knowledge of specific curriculum content areas increases, special education teachers time and focus is stretched further beyond provision of special education services. A better understanding of the effect of curriculum content knowledge of special education co-teachers on student learning and achievement will allow student services and therefore student learning to be approached with best methods. Student achievement in situations where the special educator is scheduled within only one content 
curriculum area, two content curriculum areas, and three content curriculum areas will be compared and analyzed.

An analysis of the effect of the curricula content expectation of special educators working as co-teachers will provide information that may help personnel decisions in this school, by understanding how the content knowledge of special education co-teachers impact the achievement of students in those co-taught classes. If there is a threshold where student achievement is noted to decrease, the logistics of scheduling co-teaching teams, support needed by both the general education and special education co-teacher, and the overall use of the co-taught model in a high school setting may be worth reevaluating to best serve students.

The study will utilize data and consider three of the content areas assessed by the state of Missouri with End Of Course Exams - algebra I, and biology, and government. Achievement scores on state mandated End Of Course Exams, and course grades, culled from building records history, will be analyzed using t-tests.

\section{Research Questions}

The research questions guiding this study are:

- Will special education students in classes with a special education co-teacher responsible for one curriculum content earn higher end-of-course exam scores than those in classes with a special education co-teacher responsible for two curriculum contents that school year?

- Will special education students score higher on end-of-course exams when in classrooms with special education co-teachers responsible for one curriculum 
content than those students in classrooms with special education teachers responsible for two curriculum contents in that school year?

- Will special education students score higher on end-of-course exams when in classrooms with special education co-teachers responsible for one curriculum content than those students in classrooms with special education teachers responsible for three curriculum contents in that school year?

- Will special education students earn higher final summative class grades when in classrooms with special education co-teachers responsible for one curriculum content than those students in classrooms with special education responsible for two curriculum contents in that school year?

- Will special education students earn higher final summative class grades when in classrooms with special education co-teachers responsible for one curriculum content than those students in classrooms with special education teachers responsible for two curriculum contents in that school year?

\section{Hypothesis}

- Research Question 1: There will be no difference in scores on EOC's in those classes with a special education co-teacher responsible for one course curriculum than those in classes with a special education teacher working responsible for two content area curricula in that school year.

- Research Question 2: There will be no difference in scores on EOC's in those classes with a special education co-teacher responsible for one course curriculum than those in classes with a special education teacher responsible for three content area curricula in that school year. 
- Research Question 3: There will be no difference in final summative class grades for special education students in those classes with a special education coteacher responsible for one course curriculum than those in classes with a special education teacher responsible for two content area curricula in that school year.

- Research Question 4: There will be no difference in final summative class grades for special education students in those classes with a special education coteacher responsible for one course curriculum than those in classes with a special education teacher responsible for two content area curricula in that school year.

\section{Participants and Sampling Procedures}

The High School used for this research is in a suburban community, and is the only high school in the school district. The district was formed in 1949 through the consolidation of several smaller elementary schools, and is now one of the largest districts in its County, encompassing several small and medium sized communities. The district includes eight elementary schools, two $6^{\text {th }}-8^{\text {th }}$ grade middle schools and one high school. The district serves $98.1 \%$ Caucasian students, with $31.8 \%$ receiving free or reduced lunch. The Missouri Department of Elementary and Secondary Education (DESE) reports the student population of the district over the last five consecutive years has fallen between 6,500 and 7,000 students. At the high school, it has been between 2,100 and 2,300. The incidence for special education for the district has been between ten and thirteen percent (Missouri Department of Education, 2016).

Students receiving special education services, taking Biology, English II, or Government in a co-taught setting are the subjects for this study. All students in these 
courses were included, representing a random sampling of special education students in the building who do receive special education services through the co-taught model, while taking these specific classes. These four courses are three of the four selected by the state to include End of Course examinations. Participants, made eligible only due to enrollment in these courses will remain anonymous. Data on course grades, and state assessment scoring does not require identification of participants for the purposes of the research questions. Individual data will not be reported for the purposes of this study. (See Appendices A - C for achievement data information)

The general sample will be composed a total of one hundred twenty-seven students, 45 females and 82 males. Students will include those enrolled in co-taught Algebra, co-taught Biology, or co-taught Government classes from the 2010/2011 and 2011/2012 school years. The sample population will include those students receiving special education services in these classes through the co-taught setting. The study will include non-probability sampling, utilizing a population of convenience as they represent students within the circumstances experienced by special educators that the research intends to investigate.

The instrument used for data analysis will be t-tests, to compare whether specified groups of students, achieve at different levels. An independent t-test will be conducted to compare:

- EOC achievement of students in classes where the special educator is responsible for one curriculum content and those in classes where the special educator is responsible for two. 
- EOC achievement of students in classes where the special educator is responsible for one curriculum content and those in classes where the special educator is responsible for three.

- Course grades of students in classes where the special educator is responsible for one curriculum content and those in classes where the special educator is responsible for two.

- Course grades of students in classes where the special educator is responsible for one curriculum content and those in classes where the special educator is responsible for three.

\section{Design for the Study}

The study will utilize an inferential research approach. The design will allow for an examination of data that will reflect student achievement, measured by both course grade and grades on state issued end of course examinations, in relation to the assignment of content curriculums of their special education co-teachers. Student achievement will be examined in three of the four courses that the state of Missouri requires for a high school diploma. Achievement will consider measurements of both grade earned in the class, and the grade, based score on the state end of course examination for analyzing the effect of the circumstances of the special education teacher. The use of inferential statistical allows for findings from a smaller research sample to generalized to similar or same larger populations. (Independent t-test, 2016, Trochim, 2006). Therefore, the information may be used to help inform and guide decisions regarding the scheduling and 
professional development of special educators (Lehman, O'Rourke, Hatcher, Stepanski, 2013, Trochim, 2006).

Variations of student achievement in situations where the special educator is coteaching within one content area curriculum will be compared with those where the special education co-teacher is responsible for two content area curriculums, and with those where the special education co-teacher is responsible for three curriculum content areas. The study will consider three of the content areas assessed by the state of Missouri with End of Course Exams - Algebra I, Biology, US Government and English II, reviewing the final summative grades and grade based on EOC scores for students receiving special education services in co-taught classrooms.

The t-test statistical analysis will be utilized with the collected data. The independent variable in this research is the number of course content curriculums for which the special education co-teacher is responsible. This variable will include the categories of one course content curricula, two course content curricula, and three course content curricula. Student achievement will serve as the dependent variable, measured by course grade and score on state mandated end of course examinations. Results will provide information stating if two groups are significantly different.

\section{Independent Variable:}

Number of content areas in which special educator co-teaches (One, Two, and Three)

\section{Dependent Variable:}

Student achievement measured by course grade

Student achievement measured by score on End Of Course Exam. 
It is the anticipation that research findings will have implications that can inform decisions related to special educator and general educator professional development regarding co-teaching and special education, content knowledge expectations and ongoing learning for special education teachers, and the creation and support of coteaching teams. The use of a descriptive design study is useful in planning for areas where an anticipated need for more research is warranted. Data may not only produce important recommendations, but also assist in determining components of future experimentation or research. As these questions continue to rise up within educational institutions, and the landscape adjusts to the changing expectations for special education students, much more will need to be known about how to best prepare and support special education teachers (Association for Educational Communications and Technology, 2001, US Department of Health and Human Services, nd). Data collection will include course grades by percentages at the end of the school year, and scores on the state mandated end of course examinations. A statistical analysis of both course grade and state assessment data will be reviewed.

To protect from bias, as the researcher previously worked as a special education teacher with in the building, student data will be assigned and reviewed using numerical identification to keep their names anonymous. Additionally, state test examination scoring is completed outside of the building. Teacher review or evaluation of student work on these assessments does not take place. At the high school, where research was conducted, the special education co-teachers are involved with class grades, and neither the special education co-teacher or general education teacher contribute to the scoring of 
the state exams. State tests predominantly take place at the $9^{\text {th }}$ grade level for Algebra I and Biology, the $10^{\text {th }}$ grade level for English II, and the $11^{\text {th }}$ grade level for Government.

In ensuring validity, multiple sources of student performance - both course grades and scores on EOC's are included. Data will be used from a span of 3 school years of each assignment type for special educators. Three years of building student achievement where the special educator works with general education co-teachers within a single content area, and where they work with two or more content areas with a core content team of teachers. Data on student achievement will be analyzed from both final grade for the course, and their performance on state end of course exams in two content areas. Use of peers for reviewing data collection methods and findings will take place.

It is the anticipation that results from the study will provide information that can inform decisions related to teacher education and professional development, formation of partnerships between special and general educators as co-teachers, and building decisions regarding assignment of special education teachers. The relationship design will allow for an examination of data that will reflect student achievement in relation to the number of content curriculums for which their special education is responsible.

\section{Data Collection and Instrumentation}

Data, from school years 2010/2011 through 2012/2013, will be collected from district information and information that is recorded by the Missouri Department of Elementary and Secondary Education. This will represent a span of three school years. During those years, achievement data will be compared among students of special education co-teachers responsible for only one curriculum content with students of special educators responsible for one more. The Course grade data from the end of the 
course will be used - one or two semesters depending on the full length of the class. EOC exams are given toward the end of the school year, based on the window made available by the state, and the decision of the school district. Data on both achievement measures will be retrieved from the building online gradebook program.

\section{Ethical considerations.}

A synopsis of the study, and purpose of participation will be included with the request for prior course grades and EOC scores. The data including the prior course grades and EOC scores exists in school records, and can be gathered and provided to the researcher using methods that will not identify specific students. Information of student achievement on both course grades, a and state examinations will be figured as averages, and individual student names will not be part of the data. Names, or other identifying information, will not be used or needed during the data analysis process. There are no ethical concerns related to individuals through the use of the achievement data in this research.

\section{Data Collection.}

Data will be collected through a request for district records of student course final course grades and EOC scores for the three courses. School records hold the necessary data and will be provided to the researcher for the purposes of this study. The collection will be anonymous, no identifying student information is needed for this research, and will therefore not be included. Appendices with this data, and accompanying information will be included. 
Upon conclusion of the study, participant data will be reported as group results only and a summary of these results will be made available to all interested parties. Individual, or identifying data will not be utilized or retained.

\section{Role of Researcher.}

The researcher will serve as the primary data collection tool, sending out the request for district data and seeking data from appropriate district staff members. A study synopsis, purpose of the research and intended use of the data will be provided with the request for prior course grades and EOC scores. Previous employment in the school where the research took place in the role of a special education teacher on $9^{\text {th }}$ grade teams allowed the researcher to build experience and an understanding of the work of the special education co-teacher requiring awareness of both IEP information and curriculum content area knowledge. The role of the researcher, on special education planning committees, building professional development teams and character education committees at both building and district levels has shaped perceptions of general education, of content areas, of the importance of the opportunity to build relationships with students, and the struggles for special education co-teachers unfamiliar with content areas in which they are assigned to co-teach.

The researcher brings knowledge of character education, classroom management, instructional strategies, and building structure. Due to previous experiences, and my previous role in the building, I may bring certain biases to the study. Opinions or experiences of the researcher are not part of this research study. The courses in which the researcher served as a co-teacher will not be used for data collection for this research as an additional level separating the researcher from utilized data. Every effort will be made 
to ensure objectivity, though it remains possible that the biases of the researcher may shape how the collected data, and analysis results are viewed and interpreted.

\section{Limitations and Assumptions}

Limitations of the study may exist due to this researcher's previous employment within the building, relationships with the staff, or knowledge and experiences with the subject matter(s). The researcher will make every effort toward objectivity when collecting and analyzing data. Accounting for variables such as demographics, gender, class size, or teacher experience and quality will be considered. The controlled variable will be that of number of curricula for which the special education co-teacher is responsible as the study is focused on the role that plays in student achievement.

Anonymity will be ensured as identification of specific students will not be included in data collection. Final examinations occur according to building timelines. The administration of EOC's occur during a state determined, specified window of time. All other education related state requirements are met as well. There are limited physical or long-term risks known to be associated with this study.

\section{Limitations.}

This research is limited by eligibility for participation is dependent first on student qualification for special education services as well as placement in the co-taught environment for the content areas reviewed in this study. As the researcher strives to maintain distance from the study, the main tool for data collection, students will be assigned numbers that will connect to class grades and state assessment scores as they are tabulated for averages. Data from courses taught by teachers that do not include the 
requirement of the state end of course will not be included. Through the use of a quantitative study, numerical data from course grades and state examinations will allow an efficient method to test these hypotheses. Antidotal and contextual data is not included, and may be an influencing factor of student achievement. Changes of student placement that take place through the course of a school year may also influence scores.

\section{Trustworthiness.}

Every effort will be made to bring objectivity to the data and research. Anonymity is ensured, as identifying information of students used for data collection, will not be collected. Data will include course grades as a percentage, and End of Course Examination scores in classes. All information is retrieved from building records with no identifying student information, assumed accurate, and requested and collected through sources and methods that do not include bias.

\section{Assumptions.}

The overarching assumption, that student achievement is influenced by the content area knowledge of the special education co-teacher exists. The extent of that influence, and its connection to the amount of core subject content area knowledge, in addition to special education expertise is in question.

The assumption of qualified educators, with established co-teaching partnerships is also in place. All teachers, both general education and special education teaching in the co-taught classes from which data was culled have been teaching for at least five years, and teaching together for at least three. 
Due to previous experiences, and role in the building, through the period of data collection, the researcher may bring certain biases to the study. As an educator with experience as a special education co-teacher responsible for varying numbers of curriculum content knowledge, this researcher, also believe this assumption likely true. This belief may impact interpretation and analysis of some of the data. Every effort will be made to maintain objectivity. The use of both course grades, assigned by teachers, and end of course examination, which are standardized tests created and scored by the state were utilized to include achievement data from sources other than classroom teachers.

Research will take place in a Midwestern rural high school, where the researcher was previously employed. Student achievement information will be collected anonymously, and no individual information will be utilized for the purposes of reporting data. Additionally, it will be communicated that the purpose of all data collected is for the purpose of this researcher's doctoral work. Research was limited to one Midwestern suburban high school, with approximately 130 teaching staff and 1900 students.

\section{Summary}

This chapter describes the research questions, the type of research utilized and data collection and analyzation methods. From the analysis of the data I will share results that answer the research questions - primarily reflecting on and communicating the relationship between the number of content areas in which a special educator co-teaches and the achievement of students in that special educator's classes. The study investigated this phenomenon in a Midwestern rural high school serving grades $9-12$, and 130 teachers on staff. Achievement data of one hundred twenty-seven high school 
students will be utilized. Those eligible for the utilization of scores included students receiving special education services in courses requiring end of course examinations by the state of Missouri. Data was gathered using district technology with final, end of year, summative grade and state end of course examination data.

It will be worth noting the amount of difference in student achievement in both special education co-teacher assignment circumstance. This information may be of use to guide decisions for co-teaching opportunities, sections, and professional development in the future. It also may be helpful in determining the number of content areas in which special educators are placed as co-teachers and the supports they may benefit from to ensure their familiarity and comfort with the curriculum. 


\section{CHAPTER FOUR: RESULTS AND ANALYSIS OF DATA}

\section{Introduction}

The purpose of this study was to investigate the relationship between the mastery of curriculum content of the special education co-teacher and the achievement of special education students in co-taught classes. Special education teachers are often faced with the tasks of maintaining a knowledge of diagnosed disabilities for which students receive special education services, understanding and meeting the needs of students receiving special education services, and updating educational records. The research questions of this study aim to look at the effect the number of curriculum contents a special education co-teacher is responsible for co-teaching on the achievement of the special education students in those classes.

Achievement data was collected using summative course grades and end of course examination scores. Statistical analysis, using Levene's test for equality of variances, t-tests, and Cohen's $d$ for effect size, were conducted with data for those students receiving special education services in co-taught classrooms. Student mean scores were compared from settings where the special education co-teacher is assigned responsibility for one curriculum content to those, to those in which the special education co-teacher is assigned responsibility for two or three curricula within the same school year. Through this, the relationship between student achievement and the content area knowledge expectations placed upon the special education co-teacher was explored. In this chapter, the results of data analysis are presented. 


\section{Organization of Data Analysis}

The participants of this study were high school students, receiving special education services and enrolled in co-taught classes for the subjects of Biology, English II, and Government. All three classes include an End-of-course examination, mandated by the state. end-of-year, summative, course grades, and EOC scores of students, in grades nine through twelve, ranging in age from fourteen to nineteen years old were utilized as measures of student achievement. Data from one hundred twenty-seven special education students receiving services in the co-taught classroom, forty-five males, and eighty-two females was compiled and provided for the purpose of this research. Data collection included achievement scores only, without identifying student information included. Statistical analysis, using t-tests were completed to compare student achievement measurements. Measurements from classes where the special education coteacher is responsible for one curriculum content were compared to classes where the special education co-teacher is responsible for two, and where the they are responsible for three. Analyzing data using inferential statistics provides the opportunity to apply the findings of the data from the utilized sample for application to a general population. In this research, the findings from the sample data will provide information on the achievement of the general population of students in co-taught environments, and the relationship it has to the curriculum responsibility expectations placed upon the special education co-teachers in those classrooms. (Lehman, O’Rourke, Hatcher, Stepanski, 2013, Trochim, 2006). Findings may be used to help guide professional development or 
scheduling of special education teachers and policies or decisions related to co-taught classrooms.

With the intention conducting individual independent T-tests for each of the four research questions, Levene's test for homogeneity of variance will be conducted. The assumption of homogeneity of variance is that the variance of the outcome variable should be similar for each group of data collected (Field, 2009). The statistical analysis conducted will indicate outcomes of t-tests with equal variances assumed, and with equal variances not assumed. If Levene's test is significant, confidence is gained that the variances are significantly different, and an assumption for homogeneity of variances cannot be made. If Levene's test is not significant, the assumption can be made that the variances are approximately equal (Field, 2009). Student performance, based on their summative, end of course grades, and earned scores on state mandated end-of-course examinations, allow for comparison of student achievement. Results of the t-test will inform if the means of two groups are statistically different enough to determine that the difference was due to some other characteristic (Biddix, 2009). Finally, Cohen's $d$, measuring the effect size, was conducted. Student performance based on these two measurements are available and were represented as percentage scores earned by students.

\section{Descriptive Characteristics of Participants}

Achievement measurements of high school students in grades $9-12$, receiving special education services, and enrolled in a co-taught class for course content areas mandated by the state to participate in the Missouri Assessment Program and take the content end of course examination (EOC) will be used. End-of-year, summative, course 
grades and scores on the end-of-course examinations were utilized as achievement measures. The use of 2 pieces of achievement measurement accounts for factors that may influence a score when only using one achievement measure. Of the hundred and twenty-seven participants, forty-five were female, and eighty-two were male. General education and special education teachers of students from which achievement data was included will have taught individually for at least 5 years prior to beginning data collection, and as a co-teaching team for at least 3 years prior. The group statistics for the special education students receiving special education services in co-taught classes where the special education co-teacher is responsible for either one curriculum, two curricula, and three curricula are listed below.

Table 1

Mean and Standard Deviation of student sample populations One content curriculum/Two content curricula

\begin{tabular}{|c|c|c|c|c|c|}
\hline & Setting & $\mathrm{N}$ & Mean & Std. Deviation & Std. Error Mean \\
\hline Final Course & One Curriculum & 47 & 71.7660 & 6.03329 & .88005 \\
\hline Grade & Two Curricula & 33 & 74.3636 & 11.16025 & 1.94275 \\
\hline \multirow[t]{2}{*}{$\mathrm{EOC}$} & One Curriculum & 47 & 65.7234 & 8.89236 & 1.29708 \\
\hline & Two Curricula & 33 & 67.5455 & 12.17346 & 2.11913 \\
\hline \multicolumn{6}{|c|}{ One content curriculum/Three content curricula } \\
\hline & Setting & $\mathrm{N}$ & Mean & Std. Deviation & Std. Error Mean \\
\hline Final Course & One Curriculum & 47 & 71.7660 & 6.03329 & .88005 \\
\hline Grade & Three Curricula & 47 & 76.5957 & 7.78421 & 1.13544 \\
\hline \multirow[t]{2}{*}{ EOC } & One Curriculum & 47 & 65.7234 & 8.89236 & 1.29708 \\
\hline & Three Curricula & 47 & 79.0851 & 10.83639 & 1.58065 \\
\hline
\end{tabular}




\section{Research Questions and associated Hypothesis}

The research questions guiding this study are:

- Will special education students score higher on end-of-course exams when in classrooms with special education co-teachers responsible for one curriculum content than those students in classrooms with special education teachers responsible for two curriculum contents in that school year?

- Will special education students score higher on end-of-course exams when in classrooms with special education co-teachers responsible for one curriculum content than those students in classrooms with special education teachers responsible for three curriculum contents in that school year?

- Will special education students earn higher final summative class grades when in classrooms with special education co-teachers responsible for one curriculum content than those students in classrooms with special education responsible for two curriculum contents in that school year?

- Will special education students earn higher final summative class grades when in classrooms with special education co-teachers responsible for one curriculum content than those students in classrooms with special education teachers responsible for two curriculum contents in that school year?

\section{Hypothesis}

For each research question, a null hypothesis was submitted:

- There will be no difference in scores on EOC's in those classes with a special education co-teacher responsible for one-course curriculum than those in classes 
with a special education teacher responsible for two content area curricula in that school year.

- There will be no difference in scores on EOC's in those classes with a special education co-teacher responsible for one-course curriculum than those in classes with a special education teacher responsible for three content area curricula in that school year.

- There will be no difference in final summative class grades for special education students in those classes with a special education co-teacher responsible for onecourse curriculum than those in classes with a special education teacher responsible for two content area curricula in that school year.

- There will be no difference in final summative class grades for special education students in those classes with a special education co-teacher responsible for onecourse curriculum than those in classes with a special education teacher responsible for two content area curricula in that school year.

\section{Analysis of the Data}

Results from Levene's test for equality of variances and t-tests comparing the means for the end of year, summative course grades and EOC scores for students receiving special education services in co-taught classes where the special education coteacher was responsible for one curriculum contents with those receiving special education services in co-taught classes where the co-teacher was responsible for two curricula contents, and then three curricula contents are addressed in this section. 
Group statistics, and statistical analysis results related to the end of course examination scores for students receiving special education services in co-taught classes where the special education co-teacher was responsible for one curriculum content, and those students in co-taught classes where the special education co-teacher was responsible for two curricula contents were conducted. The analysis was conducted to address research question one. Results are shown below.

Research Question 1: Will special education students score higher on end-of-course exams when in classrooms with special education co-teachers responsible for one curriculum content than those students in classrooms with special education teachers responsible for two curriculum contents in that school year?

Hypothesis 1: There will be no difference in scores on EOC's in those classes with a special education co-teacher responsible for one-course curriculum than those in classes with a special education teacher working responsibly for two content area curricula in that school year. 
Table 2

Mean and standard deviation of EOC scores of students in the first set of defined classroom environments

\begin{tabular}{llcccc}
\hline & Setting & $\mathrm{N}$ & Mean & Std. Deviation & Std. Error Mean \\
\hline \multirow{2}{*}{ EOC } & One Curriculum & 47 & 65.7234 & 8.89236 & 1.29708 \\
& Two Curricula & 33 & 67.5455 & 12.17346 & 2.11913 \\
\hline
\end{tabular}

Table 3

Results of Levene's test and t-test for EOC scores of students in the first set of defined classroom environments

\begin{tabular}{|c|c|c|c|c|c|c|c|}
\hline & & \multicolumn{2}{|c|}{$\begin{array}{c}\text { Levene's Test for } \\
\text { Equality of Variances }\end{array}$} & \multicolumn{4}{|c|}{ t-test for Equality of Means } \\
\hline & & $\mathrm{F}$ & Sig. & $\mathrm{t}$ & df & $\begin{array}{l}\text { Sig. (2- } \\
\text { tailed) }\end{array}$ & $\begin{array}{c}\text { Mean } \\
\text { Difference }\end{array}$ \\
\hline \multirow[t]{2}{*}{$\begin{array}{l}\text { Final Course } \\
\text { Grade }\end{array}$} & $\begin{array}{l}\text { Equal variances } \\
\text { assumed }\end{array}$ & 4.474 & .038 & -1.343 & 78 & .183 & -2.59768 \\
\hline & $\begin{array}{l}\text { Equal variances } \\
\text { not assumed }\end{array}$ & & & -1.218 & 45.157 & .230 & -2.59768 \\
\hline
\end{tabular}

t-test for Equality of Means (continued)

\begin{tabular}{llccc} 
& & \multicolumn{2}{c}{$\begin{array}{c}\text { 95\% Confidence Interval of the } \\
\text { Difference }\end{array}$} \\
\hline \multirow{2nnyy}{*}{$\begin{array}{l}\text { Final Course } \\
\text { Grade }\end{array}$} & $\begin{array}{l}\text { Equal variances } \\
\text { Difference }\end{array}$ & 1.93465 & -6.44927 & 1.25391 \\
\cline { 3 - 4 } & $\begin{array}{l}\text { assumed } \\
\text { Equal variances not } \\
\text { assumed }\end{array}$ & 2.13278 & -6.89291 & 1.69755 \\
\hline
\end{tabular}

An independent samples t-test was conducted to compare year-end summative course grades of students receiving special education services in a co-taught classroom where the special education co-teacher is responsible for one-course curriculum and where the special education co-teacher is responsible for two-course curriculums. The 
independent samples t-test showed there was not a significant difference in the end-ofcourse exam scores of students in co-taught classes where the special education coteacher was responsible for one curriculum content $(\mathrm{n}=47, \mathrm{M}=65.7, \mathrm{SD}=8.8)$ and those in classes where the special education co-teacher was responsible for two curricula contents $(M=67.5, S D=12.1)$ conditions; $t(78)=-774, p=.441$. Further, Cohen's effect size value $(d=.17)$ suggested a small practical significance.

The researcher hypothesized that there would be no difference in scores on EOC's in those classes with a special education co-teacher responsible for one-course curriculum than those in classes with a special education teacher working responsibly for two content area curricula. Scores for the two groups did not differ significantly according to t-test results, $\mathrm{t}(78)=-774, \mathrm{p}(.441)>.05$. On average students in classrooms with a special education co-teacher responsible for one-course curriculum earned an end of course examination score of 65.72 percent, while students in classrooms with a special education co-teacher responsible for two-course curricula earned an end of course examination score of 67.54 percent. The $95 \%$ confidence interval for the effect of the number of course curricula for which the special education co-teacher was responsible is between -6.50 and 2.86 percent. There is not a statistically significant difference in scores on EOC's in those classes with a special education co-teacher responsible for one course curriculum than those in classes with a special education teacher working responsibly for two content area curricula. The null hypothesis that there is no difference in end-of-course examination scores is not rejected, these results support the researchers' hypothesis.

Group statistics, and statistical analysis results related to the end of course examination scores for students receiving special education services in co-taught classes 
where the special education co-teacher was responsible for one curriculum content, and those students receiving special education services in co-taught classes where the special education co-teacher was responsible for three curricula contents were conducted. The analysis was conducted to address research question two. Results are shown below. Research Question 2: Will special education students score higher on end-of-course exams when in classrooms with special education co-teachers responsible for one curriculum content than those students in classrooms with special education teachers responsible for three curricula contents in that school year?

Hypothesis 2: There will be no difference in scores on EOC's in those classes with a special education co-teacher responsible for one-course curriculum than those in classes with a special education teacher responsible for three content area curricula in that school year. 
Table 4

Mean and standard deviation of EOC scores of students in the second set of defined classroom environments

\begin{tabular}{llcccc}
\hline & Setting & $\mathrm{N}$ & Mean & Std. Deviation & Std. Error Mean \\
\hline EOC & One Curriculum & 47 & 65.7234 & 8.89236 & 1.29708 \\
& Three Curricula & 47 & 79.0851 & 10.83639 & 1.58065 \\
\hline
\end{tabular}

Table 5

Results of Levene's test and t-test for EOC scores of students in the second set of defined classroom environments

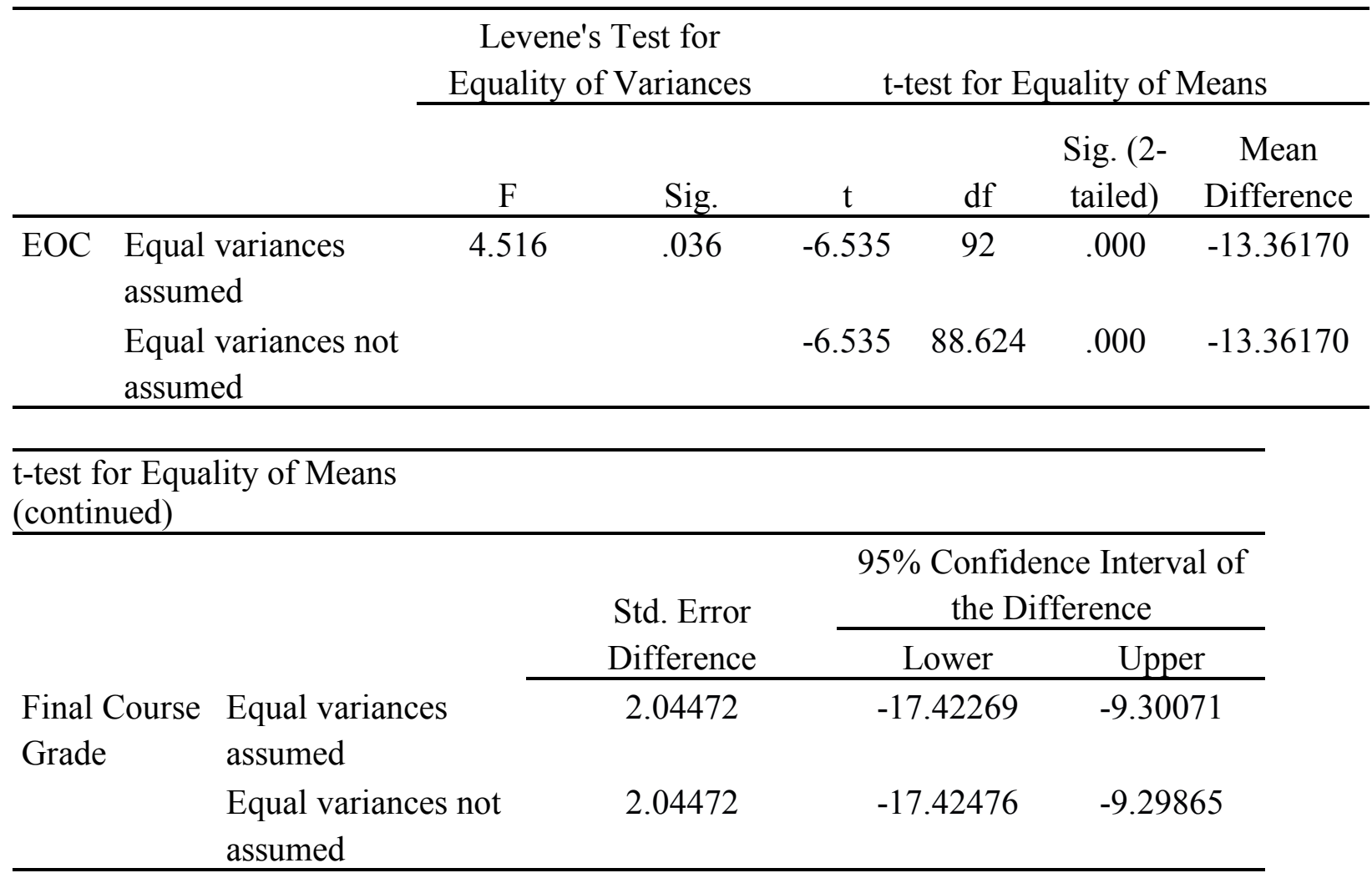

An independent samples t-test was conducted to compare year-end of course grades of students receiving special education services in a co-taught classroom where the special education co-teacher is responsible for one-course curriculum and where the special education co-teacher is responsible for three-course curriculums. The independent 
samples t-test showed there was a significant difference in the end-of-course exam scores of students in co-taught classes where the special education co-teacher was responsible for one curriculum content $(\mathrm{n}=47, \mathrm{M}=65.7, \mathrm{SD}=8.8)$ and those in classes where the special education co-teacher was responsible for three curricula contents $(n=47 \mathrm{M}=$ 79.08, $\mathrm{SD}=10.83)$ conditions; $\mathrm{t}(92)=6.53, \mathrm{p}=.001$. Further, Cohen's effect size value $(d=1.35)$ suggested a large practical significance.

The researcher hypothesized that there would be no difference in scores on end of course examinations in those classes with a special education co-teacher responsible for one-course curriculum than those in classes with a special education teacher working responsibly for three content area curricula. Scores for the two groups did differ significantly according to t-test results, $\mathrm{t}(92)=6.53, \mathrm{p}(.001)<.05$. On average students in classrooms with a special education co-teacher responsible for one-course curriculum earned an end of course examination score of 65.72 percent, while students in classrooms with a special education co-teacher responsible for three-course curricula earned an average end-of-course examination score of 79.08 percent. The $95 \%$ confidence interval for the effect of the number of course curricula for which the special education co-teacher was responsible is between -17.42 and -9.29 percent. There is a statistically significant difference in scores on EOC's in those classes with a special education co-teacher responsible for one-course curriculum than those in classes with a special education teacher working responsibly for three content area curricula. The null hypothesis that there is no difference in end-of-course examination scores is rejected; these results do not support the researchers' hypothesis. 
Group statistics, and statistical analysis results related to the final, summative, end of year, class grades for students receiving special education services in co-taught classes where the special education co-teacher was responsible for one curriculum content, and those students receiving special education services in co-taught classes where the special education co-teacher was responsible for two curricula contents were conducted. The analysis was conducted to address research question three. Results are shown below. Research Question 3: Will special education students earn higher final, summative, end of year, class grades when in classrooms with special education co-teachers responsible for one curriculum content than those students in classrooms with special education responsible for two curriculum contents in that school year?

Hypothesis 3: There will be no difference in final summative class grades for special education students in those classes with a special education co-teacher responsible for one-course curriculum than those in classes with a special education teacher responsible for two content area curricula in that school year.

Table 6

Mean and standard deviation of EOC scores of students in the third set of defined classroom environments

\begin{tabular}{llcccc}
\hline & Setting & $\mathrm{N}$ & Mean & Std. Deviation & Std. Error Mean \\
\hline Final Course & One Curriculum & 47 & 71.7660 & 6.03329 & .88005 \\
Grade & Two Curricula & 33 & 74.3636 & 11.16025 & 1.94275 \\
\hline
\end{tabular}


Table 7

Results of Levene's test and t-test for EOC scores of students in the third set of defined classroom environments

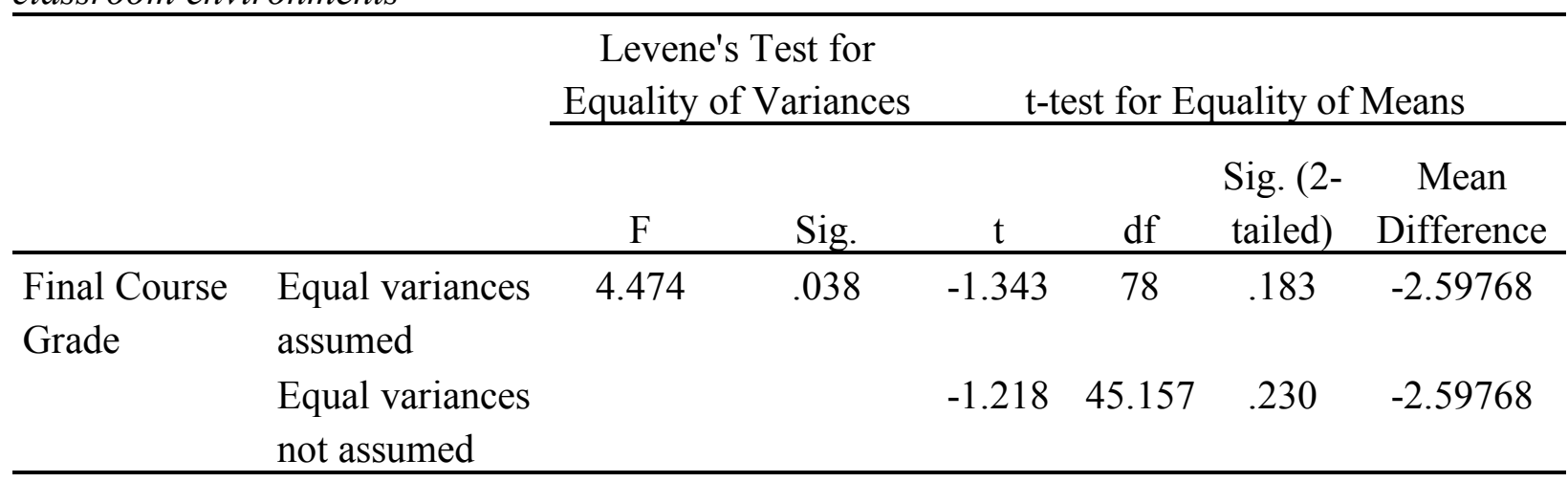

t-test for Equality of Means

(continued)

$95 \%$ Confidence Interval of the

\begin{tabular}{llccc} 
& & Std. Error & \multicolumn{2}{c}{ Difference } \\
\cline { 3 - 5 } & & Difference & Lower & Upper \\
\hline Final Course & Equal variances & 1.93465 & -6.44927 & 1.25391 \\
Grade & $\begin{array}{l}\text { assumed } \\
\text { Equal variances not } \\
\text { assumed }\end{array}$ & 2.13278 & -6.89291 & 1.69755 \\
\hline
\end{tabular}

An independent samples t-test was conducted to compare final, year-end, summative course grades of students receiving special education services in a co-taught classroom where the special education co-teacher is responsible for one-course curriculum and where the special education co-teacher is responsible for two-course curriculums. The independent samples t-test showed there was not a significant difference in the end-of-course exam scores of students in co-taught classes where the special education co-teacher was responsible for one curriculum content $(n=47, M=$ $71.76, \mathrm{SD}=6.03$ ) and those in classes where the special education co-teacher was responsible for two curricula contents $(\mathrm{n}=33, \mathrm{M}=74.36, \mathrm{SD}=11.16)$ conditions; $\mathrm{t}$ 
$(45.16)=-1.22, \mathrm{p}=.230$. Further, Cohen's effect size value $(d=.29)$ suggested a small practical significance.

The researcher hypothesized that there would be no difference in scores on EOC's in those classes with a special education co-teacher responsible for one-course curriculum than those in classes with a special education teacher working responsibly for two content area curricula. Scores for the two groups did not differ significantly according to t-test results, $\mathrm{t}(45.16)=-1.22, \mathrm{p}(.230)>.05$. On average students in classrooms with a special education co-teacher responsible for one-course curriculum earned a final, yearend, summative course grade of 71.76 percent, while students in classrooms with a special education co-teacher responsible for two-course curricula earned an end of course examination score of 74.36 percent. The $95 \%$ confidence interval for the effect of the number of course curricula for which the special education co-teacher was responsible is between -6.89 and 1.69 percent. There is not a statistically significant difference in scores on final, year-end, summative course grades in those classes with a special education co-teacher responsible for one-course curriculum than those in classes with a special education teacher working responsibly for two content area curricula. The null hypothesis that there is no difference in end-of-course examination scores is not rejected, these results support the researchers' hypothesis.

Group statistics, and statistical analysis results related to the final, summative, end of year, class grades for students receiving special education services in co-taught classes where the special education co-teacher was responsible for one curriculum content, and those students receiving special education services in co-taught classes where the special 
education co-teacher was responsible for three curricula contents were conducted. The analysis was conducted to address research question three. Results are shown below. Research Question 4: Will special education students earn higher final summative class grades when in classrooms with special education co-teachers responsible for one curriculum content than those students in classrooms with special education teachers responsible for three curriculum contents in that school year?

Hypothesis 4: There will be no difference in final summative class grades for special education students in those classes with a special education co-teacher responsible for one-course curriculum than those in classes with a special education teacher responsible for three content area curricula in that school year.

Table 8

Mean and standard deviation of EOC scores of students in the fourth set of defined classroom environments

\begin{tabular}{llcccc}
\hline & Setting & N & Mean & Std. Deviation & Std. Error Mean \\
\hline Final Course & One Curriculum & 47 & 71.7660 & 6.03329 & .88005 \\
Grade & Three Curricula & 47 & 76.5957 & 7.78421 & 1.13544 \\
\hline
\end{tabular}


Table 9

Results of Levene's test and t-test for EOC scores of students in the fourth set of defined classroom environments

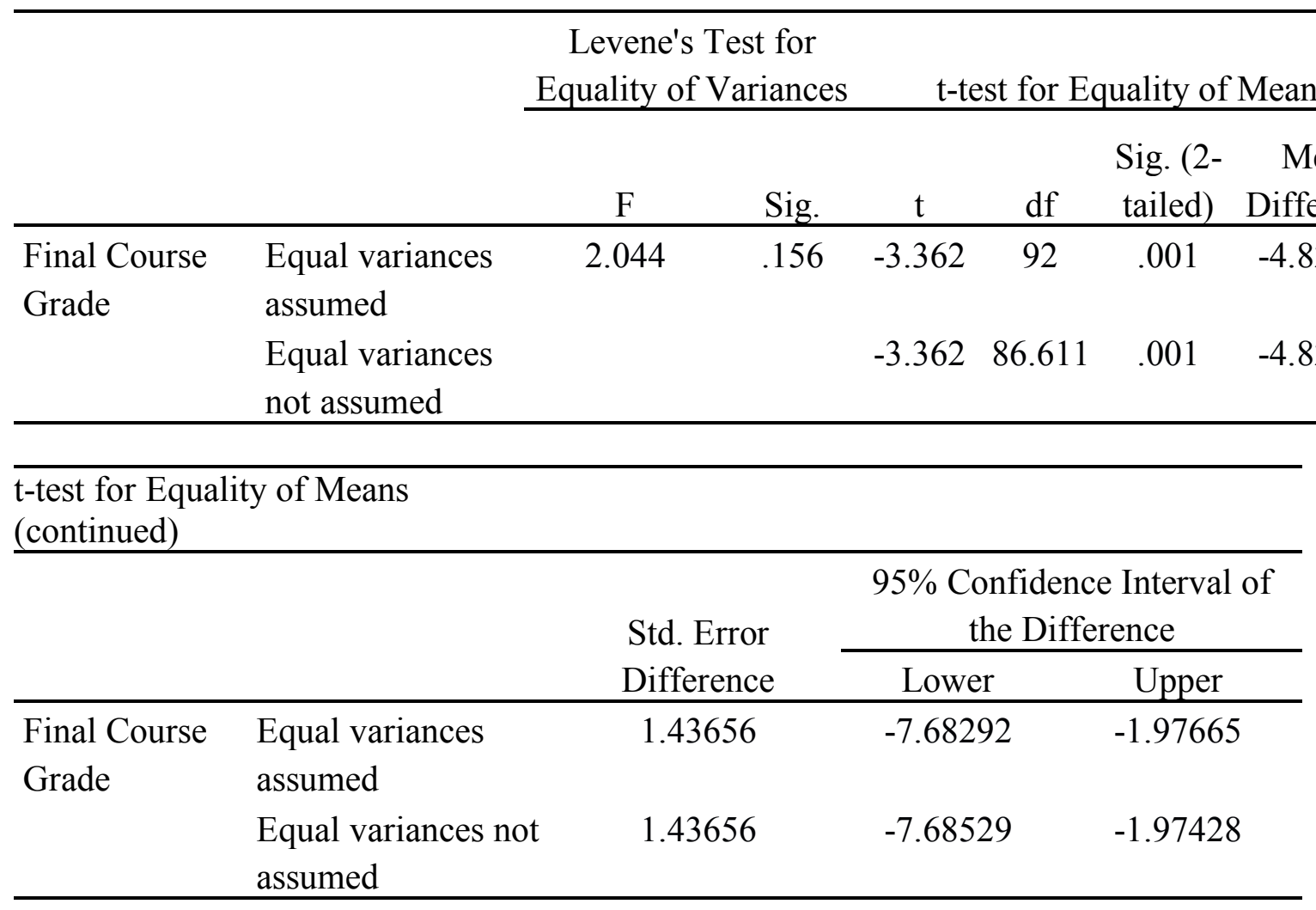

An independent samples t-test was conducted to compare final, year-end, summative course grades of students receiving special education services in a co-taught classroom where the special education co-teacher is responsible for one-course curriculum and where the special education co-teacher is responsible for three-course curricula. The independent samples t-test showed there was not a significant difference in the final, year-end, summative course grades of students in co-taught classes where the special education co-teacher was responsible for one curriculum content ( $n=47, M=$ 71.76, $\mathrm{SD}=6.03$ ) and those in classes where the special education co-teacher was responsible for three curricula contents $(n=47, M=76.59, S D=7.78)$ conditions; $t(92)=$ 
$3.36, \mathrm{p}=.001$. Further, Cohen's effect size value $(d=.1 .35)$ suggested a large practical significance.

The researcher hypothesized that there would be no difference in scores on final, year-end, summative course grades in those classes with a special education co-teacher responsible for one-course curriculum than those in classes with a special education teacher working responsibly for three content area curricula. Scores for the two groups did differ significantly according to t-test results, $\mathrm{t}(92)=3.36, \mathrm{p}(.001)<.05$. On average students in classrooms with a special education co-teacher responsible for onecourse curriculum earned final, year-end, a course grade of 71.76 percent, while students in classrooms with a special education co-teacher responsible for two-course curricula earned an end-of-course examination score of 76.59 percent. The $95 \%$ confidence interval for the effect of the number of course curricula for which the special education co-teacher was responsible is between -7.68 and -1.97 percent. There is a statistically significant difference in scores on final, end-of-year, summative course grades in those classes with a special education co-teacher responsible for one-course curriculum than those in classes with a special education teacher working responsibly for three content area curricula. The null hypothesis that there is no difference in final, year-end, coursegrades is rejected, these results support the researchers' hypothesis.

\section{Summary}

Through this chapter, the findings of Levene's test for homogeneity of variance, ttest results, and Cohen's $d$ for effect size. were presented and analyzed. Each research question, comparing achievement measures of students receiving special education 
services in co-taught classes where the special education co-teacher was responsible for one curriculum content to those of students receiving special education services where the special education co-teacher was responsible for two curriculum contents, and again where the special education co-teacher was responsible for three was analyzed individually. The hypotheses for research questions one and three were not rejected, as the differences in both final, end-of-year, summative course grades and EOC scores was not statistically significant. The hypotheses for research questions two and four were rejected, as the differences in both final, end-of-year, summative course grades and EOC scores was statistically significant. Reviewing the findings of the t-tests making the comparisons will inform each research question, and allow the researcher to reject or not reject each hypothesis. From this, the relationship between student achievement and the number of curriculum contents for which a special education co-teacher is responsible can be explored. 


\section{CHAPTER FIVE: \\ FINDINGS, CONCLUSIONS, AND IMPLICATIONS}

Students enter classrooms from a wide variety of backgrounds, with a broad spectrum of abilities. Those with diagnosed disabilities are eligible for special education services to support learning needs. The co-taught classroom is one option often utilized to provide those supports. Special education teachers are faced with the duality of maintaining a knowledge base of disabilities to meet the educational needs of students receiving special education services and gaining or maintaining a sufficient knowledge base of the curriculum content area in which they co-teach. The intent of this study was to look at the relationship between the number of content curriculums special education co-teachers are teaching, and the achievement of the special education students in those classes. This chapter presents a summary of the study, research questions with related hypothesis and findings, conclusions from the findings, implications of the results, and suggestions for possible future research.

\section{Summary of the Study}

Special Education co-teachers face the unique challenge of dual responsibilities in the general education setting. In addition to providing the complex supports for special education students, they also need to be well versed in the content area they are coteaching. The study was conducted to look for a relationship between student achievement in co-taught general education classrooms and the number of curriculum content areas in which the special educator was teaching. Levene's test for equality of 
variances, and t-tests were conducted to analyze differences in achievement measurements of special education students in co-taught classroom environments where the special education co-teacher was responsible for one content curriculum and the measurements of students where the special education co-teacher was responsible for two, and again when the special education co-teacher was responsible for three. Achievement measurements included were summative, end-of-the-course grade and EOC score earned by students. Findings from Levene's test inform the determination of a need for utilizing t-test results suited for data where equal variances are assumed, or for data where equal variances are not assumed. Findings from the t-tests address the research questions posed in chapter one of this dissertation. The population of convenience utilized represented students in three different courses - Biology, English II, and Government; all required a state-mandated Missouri Assessment Program content EOC. The achievement data were collected from school years the researcher worked as a special education co-teacher within the building. Data from the classes in which she taught were not used as part of the analyzation for this study. Achievement measures used were of high school students, grades $9-12$, receiving special education services and enrolled in a co-taught class for content areas that were mandated by the state to participate in the Missouri Assessment Program and take the content EOC. Of the hundred and twenty-seven participants, forty-five were female, and eighty-two were male. T-tests were used to address each research question individually. Analysis of the research explores the four research questions related to the number of curricula content areas the special education teacher is assigned; and to the achievement of students receiving special education services in those classes. 


\section{Findings}

Question 1: Will special education students score higher on end-of-course exams when in classrooms with special education co-teachers responsible for one curriculum content than those students in classrooms with special education teachers responsible for two curriculum contents in that school year?

Hypothesis 1: There will be no difference in scores on EOC's in those classes with a special education co-teacher responsible for one-course curriculum than those in classes with a special education teacher working responsibly or two content area curricula in that school year.

Findings support this hypothesis. Findings demonstrate a failure to reject the null hypothesis. Scores for the two groups did not differ significantly according to t-test results, $\mathrm{t}(78)=-774, \mathrm{p}(.441)>.05$. Cohen's effect size value $(d=.17)$ suggested a small practical significance.

Question 2: Will special education students score higher on end-of-course exams when in classrooms with special education co-teachers responsible for one curriculum content than those students in classrooms with special education teachers responsible for three curriculum contents in that school year?

Hypothesis: There will be no difference in scores on EOC's in those classes with a special education co-teacher responsible for one course curriculum than those in classes with a special education teacher responsible for three content area curricula in that school year. 
Findings do not support this hypothesis. Findings indicate a rejection of the null hypothesis. Scores for the two groups did differ significantly according to t-test results, $t$ $(92)=6.53, \mathrm{p}(.001)<.05$. Cohen's effect size value $(d=1.35)$ suggested a large practical significance.

Question 3: Will special education students earn higher final, end of year, summative class grades when in classrooms with special education co-teachers responsible for one curriculum content than those students in classrooms with special education responsible for two curriculum contents in that school year?

Hypothesis: There will be no difference in final summative class grades for special education students in those classes with a special education co-teacher responsible for one course curriculum than those in classes with a special education teacher responsible for two content area curricula in that school year.

Findings do support this hypothesis. Findings indicate a failure to reject the null hypothesis. Scores for the two groups did not differ significantly according to t-test results, $\mathrm{t}(45.16)=-1.22, \mathrm{p}(.230)>.05$. Cohen's effect size value $(d=.29)$ suggested a small practical significance.

Question 4: Will special education students earn higher final summative class grades when in classrooms with special education co-teachers responsible for one curriculum content than those students in classrooms with special education teachers responsible for three curriculum contents in that school year?

Hypothesis: There will be no difference in scores on EOC's in those classes with a special education co-teacher responsible for one course curriculum than those in classes 
with a special education teacher working responsible for three content area curricula in that school year.

Findings support this hypothesis. Findings indicate a failure to reject the null hypothesis. Scores for the two groups did differ significantly according to t-test results, $t(92)=3.36$, $\mathrm{p}(.001)<.05$. Cohen's effect size value $(d=.1 .35)$ suggested a large practical significance.

\section{Conclusions}

For both achievement measurements, the end-of-year summative course grade, and score on the state-mandated end-of-course examinations, when the number of curricula content areas for which the special education co-teacher was responsible increased from one curriculum to two curricula, the differences were not statistically significant. When the number of content areas were increased to three for the special education co-teacher, the differences were statistically significant. At first glance, this may seem indicative of the increase of curriculum content knowledge expectations negatively affecting student achievement. As the researcher anticipated, a statistically significant difference was found between students where there were greater curricula knowledge expectations placed upon the special education co-teacher.

This study utilized t-tests, which compares group means to see if the difference is statistically significant. The mean or average, a descriptive statistic, provides a model of the data, and uses all values in a data set when calculated (Field, 2009, Descriptive and Inferential, 2016). Descriptive statistics can summarize, describe, or show data, they do not provide a method by which conclusions or generalizations to a larger population 
(Descriptive and Inferential, 2016). The t-test is an inferential statistical tool which allows an estimation or prediction for a larger population from data of a smaller sample. Through the use of the SPSS program, output for the t-test displays tow tables, summary statistics and main test statistics. The use of the results from the t-test allows for hypothesis testing, which leads to rejection or support of a research hypothesis, providing predictions that can be applied to a larger population within a specified confidence interval (Field, 2009).

Data indicated a failure to reject the null hypothesis, with a significant difference between student achievement in classes when the number of curricula content areas for which the special education co-teacher was responsible for increased from one to three. The anticipation of the researcher however, was that statistically significant differences would be based on the challenges of greater curricula knowledge expectations. For this to be the case students receiving special education services in co-taught classes where the special education co-teacher was responsible for fewer curricula content areas would perform better on achievement measures. The means of the achievement measures in situations where the special education co-teacher was responsible for one, two, and three curricula were also reviewed. In this study, the students receiving special education services in co-taught classes where the special education co-teacher was responsible for a greater number, not fewer, of curricula content areas performed better on both achievement measures. This can be seen in mean scores of the two groups, in the group statistics. 
Table 10

Mean and Standard Deviation of student sample populations

One content curriculum/Two content curricula

\begin{tabular}{|c|c|c|c|c|c|}
\hline & Setting & $\mathrm{N}$ & Mean & Std. Deviation & Std. Error Mean \\
\hline Final Course & One Curriculum & 47 & 71.7660 & 6.03329 & .88005 \\
\hline Grade & Two Curricula & 33 & 74.3636 & 11.16025 & 1.94275 \\
\hline \multirow[t]{2}{*}{ EOC } & One Curriculum & 47 & 65.7234 & 8.89236 & 1.29708 \\
\hline & Two Curricula & 33 & 67.5455 & 12.17346 & 2.11913 \\
\hline \multicolumn{6}{|c|}{ One content curriculum/Two content curricula } \\
\hline & Setting & $\mathrm{N}$ & Mean & Std. Deviation & Std. Error Mean \\
\hline Final Course & One Curriculum & 47 & 71.7660 & 6.03329 & .88005 \\
\hline Grade & Three Curricula & 47 & 76.5957 & 7.78421 & 1.13544 \\
\hline \multirow[t]{2}{*}{ EOC } & One Curriculum & 47 & 65.7234 & 8.89236 & 1.29708 \\
\hline & Three Curricula & 47 & 79.0851 & 10.83639 & 1.58065 \\
\hline
\end{tabular}

The mean of the final, end of year, summative class grade for those students receiving special education services in co-taught classes where the special education coteacher was responsible for one curriculum was 71.76 , while the mean for those students receiving special education services in co-taught classes where the special education coteacher was responsible for two curricula was 74.36 and the mean for students receiving special education services in co-taught classes where the special education co-teacher was responsible for three curricula was 79.59. The mean of the EOC for those students receiving special education services in co-taught classes where the special education coteacher was responsible for one curriculum was 65.72 , while the mean those students receiving special education services in co-taught classes where the special education coteacher was responsible for two curricula was 67.54, and the mean of the EOC for those students receiving special education services in co-taught classes where the special education co-teacher was responsible for three curricula was 76.59. The mean score of the students in co-taught classes where the special education co-teacher was responsible 
for one curriculum was lower than when the special education co-teacher was responsible for two or three curricula. It is of interest to note that the group statistics show mean scores that are higher for students in classes where the teacher is responsible for fewer curricula. Mean scores, however, do not provide enough information to indicate if the differences are of statistical significance, or could be applied to the larger population this sample represents. While the descriptive statistics provide information that, when combined with the significant difference results from the t-test, could indicate other factors affecting student scores, additional research is needed for further conclusions.

\section{Implications}

From the conclusions, several implications follow. An effect on the achievement of students receiving special education services in co-taught classes, based on the number of content curricula contents a special education co-teacher was not concluded from the data. As discussed, a statistically significant difference in achievement for those students receiving special education services in co-taught classes where the special education coteacher was responsible for one content curriculum and where the special education coteacher was responsible for two, was not seen. A statistically significant difference in achievement for those students receiving special education services in co-taught classes where the special education co-teacher was responsible for one content curriculum and where the special education co-teacher was responsible for three, however, was seen. With an anticipation that the number of curricula effected student achievement, an expectation that students would have performed higher in those classes where the special education co-teacher was responsible for fewer course content curricula was in place. 
The higher mean scores on both achievement measures for students in classes in which the special education co-teacher was responsible for one curriculum content demonstrates that this was not the case. The implication of higher achievement in classes where the special education teacher was responsible for fewer curricula is that another factor, or other factors affected achievement more than the number of curricula for which the special education co-teacher was responsible.

With this information, the role of the special education co-teacher in the co-taught classroom can be further examined. If there is an emphasis on the special education teacher's familiarity and knowledge of the content material, in order to support and improve student achievement, time and energy is spent striving to develop a foundation or knowledge base for special education co-teachers, when it may be less necessary than commonly thought. With an implication that students perform at approximately the same levels, regardless of the number of content areas in which a special education co-teacher is teaching, the opportunity to decrease the pressure for content knowledge exists. With this decrease, other areas of focus and emphasis for those students receiving special education services in co-taught classes could receive increased attention, potentially having a positive effect on student achievement.

The data utilized for this study included achievement of students receiving special education services in different content area co-taught classes - Biology, English II, and Government. The intention of the study focused on the number of curricula for which a special education co-teacher was assigned to teach, and there was a statistically significant difference in the achievement of students when the number of those curricula increased. With the use of a population of convenience, limitations were present. Data 
was culled and utilized from one school, serving a primarily middle to lower class socioeconomic community. While the co-teaching partnerships were established relationships, controls for teacher quality or experience for either teacher individually were not in place. The range of student achievement data was based on the enrollment in classes at the time of the study. The research design did not look at other student factors, such as gender, previous school success, or demographics, and control for those variables. Implications of the study are therefore predominantly applicable for this specific school. With the likelihood that other factors affect achievement to a greater degree, research implies that the course curriculum content, the complexity or difficulty level of the content, individual student situations or ability levels, or factors relating to the general education teaching strategies, make more of a difference in the achievement of this population. The number of curricula assigned to the special education co-teacher, and the effect those variables had on student achievement, was the focus of the study. Therefore, the primary variable of a number of curricula for which the special education co-teacher was responsible was controlled for in the study. Future research could lead to opportunities to apply implications of findings to a broader range of school settings.

\section{Future Research}

The difference in achievement measure outcomes that was seen indicates that factors other than the number of curricula content areas of special education co-teachers are affecting student achievement. Continuing to consider components of student learning and achievement in co-taught classrooms, will allow educators to better identify those that play the greatest role in supporting students. The better co-teaching 
partnerships are able to increase awareness of how the role of the general education and special education teacher can be best utilized, the more the co-taught setting will serve helping students achieve at the levels at which they are capable.

Based on the data, findings, and conclusions, the following topics for additional research are suggested:

Additional or related research may consider a similar research method with adjustments such as additional pieces of data to represent student achievement. Students receiving special education services may be better able to demonstrate ability, progress, and learning with other achievement measurements.

The data utilized for this study included achievement of students receiving special education services in different content area co-taught classes - Biology, English II, and Government. With the likelihood that other factors affected achievement, conducting a similar review and statistical analysis of achievement measures for students in classes of the same conditions, for the same course as opposed to different courses. Utilization of only one specified course, over a period of several years may better demonstrate the relationship between student achievement and influencing factors.

With a continued focus on one specific school, further investigation of when, during their high-school career, students take the courses in which an end of course examination may be beneficial to school districts grappling with state test scores. For purposes of expanding the research, variables relating to demographics, such as socioeconomic levels, gender, or chronological age could be controlled. Previous academic achievement may also play a role in performance on End of Course Examinations, as they may include cumulative curriculum content that was built upon in the current course. 
Qualitative research could include interviews or surveys of general education teachers and special education teachers, students, and families of students that could investigate common experiences or themes related to student achievement. This would better inform researchers on additional factors that may affect student achievement, such as student backgrounds or abilities, general education teaching methods, or the relationship between the general education co-teacher and the special education coteacher.

\section{Summary}

Exploration of the relationship between the achievement of students receiving special education services and the number of curricula for which the special education co-teacher was responsible was the purpose of this study. With the need to support students diagnosed with a disability that impacts learning and co-teach in the general education settings special education teachers are often challenged to support students in multiple course curriculum contents. Special education co-teachers often do not have the curriculum course content knowledge base of the curriculum course content for which they are responsible to co-teach. The researcher set out to investigate the effect of special education co-teacher curricula content expertise expectations on the achievement of students receiving special education services in the general education co-taught setting when the special education co-teacher was teaching in more than one-course curriculum content.

Research questions and associated hypotheses guided the research to look at the achievement of students receiving special education services in the co-taught classroom. 
Achievement measures were student final, end-of-year, summative course grades, and end of course examination scores. The achievement mean of each measurement was compared and analyzed using t-tests. This analysis was conducted for two different situations. The first to demonstrate if a statistically significant difference was seen in student achievement in when the special education co-teacher was responsible for onecourse curriculum content and when they were responsible for two-course curricula. The second to demonstrate if a statistically significant difference was seen in student achievement in when the special education co-teacher was responsible for one-course curriculum content and when they were responsible for three-course curricula.

The results of the statistical analysis showed that there was not a statistically significant difference in achievement for those students receiving special education services in co-taught classes where the special education co-teacher was responsible for two. The results also showed that there was a statistically significant difference in achievement for those students receiving special education services in co-taught classes where the special education co-teacher was responsible for one content curriculum and where the special education co-teacher was responsible for three.

The means of the achievement measures in situations where the special education co-teacher was responsible for one, two, and three curricula were also reviewed. For both final, end-of-year, summative class grades, and end of course examination scores, the means core of the students in classes where the special education co-teacher was responsible for one curriculum was lower than when the special education co-teacher was responsible for two or three curricula. 
Considering the results of the statistical analysis, and reviewing the means of the achievement measures of both groups of students, a negative effect on student achievement, based on an increased number of curriculum content areas for which the special education co-teacher is responsible was not concluded. The difference in achievement measures that was seen indicates that there are other factors affecting student achievement in these classes, of which information can be investigated in future research of the topic. 


\section{Bibliography}

2U, Inc. (2016) Certification Map: Teacher Certification Made Simple! Retrieved from: https:/certificationmap.com/states/missouri-teacher-certification/

The Association for Educational Communications and Technology (2001). What is

DescriptiveResearch? The Handbook of Research for Educational Communications and Technology Retrieved from: http://www.aect.org/edtech/ed1/41/41-01.html

Americans with Disabilities Act of 1990, Pub. L. No. 101-336, § 2, 104 Stat 328 (1991).

Biddix, Patrick J. (2009). Significance Testing (t-tests). Retrieved from: https://researchrundowns.com/quantitative-methods/significance-testing/

Blum, R. W. (2005). A case for School Connectedness. Educational Leadership, 62(7), 16-20. Retrieved from: http://www.ascd.org/publications/educational leadership/apr05/vol62/num07/A-Case-for-School-Connectedness.aspx

Boser, Ulrich, (2009). Special Education: Teachers. Retrieved from Center for Public Education website: http://www.centerforpubliceducation.org/MainMenu/Evaluating-performance/Special-education-At-a-glance/Special-educationTeachers.html

Conduct and Interpret a One-Way MANOVA - Statistics Solutions. (2016). Statistics Solutions. Retrieved 4 September 2016, from http://www.statisticssolutions.com/conduct-interpret-one-way-manova/ Co-Teaching Connection - Assistive Technology Resources. (n.d.). Retrieved September 06, 2016, from http://www.marilynfriend.com/basics.htm 
Cresswell, J. (2009). Research Design Qualitative, Quantitative and Mixed Methods Approaches. CA: Sage Publications

Descriptive and Inferential Statistics. (2016). Statistics.laerd.com. Retrieved from:

https://statistics.laerd.com/statistical-guides/descriptive-inferential-statistics.php

Deci, E. L., \& Ryan, R. M. (1985). Intrinsic motivation and self-determination in human behavior. New York: Plenum

Dunn, L.M. (1968). Special education for the mildly retarded-Is much of it justifiable? Exceptional Children, 34 (September), 5-21

Estevez, K., Rao, S. (2008) The Evolution of Special Education: Retracing Legal Milestones in American History. Retrieved from: http://digitalcommons.butler.edu/cgi/viewcontent.cgi?article=1074\&context=coe papers

Eshilian, L., Falvey, M.A., Bove, C. Hibbard, M.J., Laiblin, J, Miller, C. \& Rosenberg, R. (2000). Restructuring to create a high school community of learners. In R. A.

Villa \& J. S. Thousand (Eds.). Restructuring for caring and effective education: piecing the puzzle together (pp. 402-427). Baltimore, MD: Paul H. Brookes Publishing.

Field, A. (2009). Discovering statistics using SPSS: (and sex and drugs and rock ' $n$ ' roll). London: SAGE Publications.

Friend, M., \& Cook, L. (1990). Pragmatic issues in the development of special education consultation programs. Preventing School Failure, 35(1), 43-46.

Friend, M., \& Cook, L. (1996). Interactions: Collaboration skills for school professionals (6thEd.). White Plains, NY: Longman. 
Friend, M. (2008). Co-Teaching: A Simple Solution that isn't Simple After All. Journal Of Curriculum and Instruction Volume 2 (2), pp. 9 - 19 Retrieved from: http://www.joci.ecu.edu/index.php/JoCI/article/viewFile/17/26

Friend, M, Cook, L, Hurley-Chamberlain, D, and Shamberger, C (2010). Co-Teaching: An Illustration of the Complexity of Collaboration in Special Education. Journal Of Educational And Psychological Consultation, Vol. 20 (1), pp 9 - 27 doi:10.3776/joci2008.v2n2p9-19

Gewertz, C. (2007). An advisory advantage. Education Week, 26(26), 22-25. Retrieved from: http://www.edweek.org/ew/articles/2007/03/07/26

Hagan-Burke, S., \& Jefferson, G. L. (2002). Using data to promote academic benefit for included students with disabilities. Preventing School Failure, 46(3), 112-118.

Hall, P, Wolfe, T. (2003). Making Inclusion a Reality for Students with Severe Disabilities. (pp. 56-60). TEACHING Exceptional Children, 35 (4). Retrieved from: http:/www.thinkinclusive.us/wpcontent/uploads/2012/09/SSN_ Article_MakingInclusionAReality.pdf

Hamre, B. K. and Pianta, R. C. (2005), Can Instructional and Emotional Support in the First-Grade Classroom Make a Difference for Children at Risk of School Failure?. Child Development, 76: 949-967. doi: 10.1111/j.1467-8624.2005.00889.x

Hatch, Amos J. (2002). Doing Qualitative Research in Education Settings. Albany, NY: State University of New York Press

Hidi, S., \& Harackiewicz, M.M. (2000). Motivating the academically unmotivated: A critical issue for the 21st century. Review of Educational Research, 70, 151-179 
Hoppey, D., \& McLeskey, J. (2013). A case study of principal leadership in an effective, Inclusive school. The Journal of Special Education, 46, 245-256. doi: $10.1177 / 0022466910390507$

Hughes, Jan N.\& Cavell, Timothy A. (1999). Influence of the teacher-student relationship in childhood conduct problems: A prospective study, Journal of Clinical Child Psychology 28:2, 173-184 Retrieved from: http://dx.doi.org/10.1207/s15374424jccp2802_5

IDEA - Building The Legacy of IDEA 2004. (n.d.). Retrieved June 3, 2015, from http://idea.ed.gov/explore/view/p/,root,regs,300,B,300\%2E115

Idol, L. (2006). Toward inclusion of special education students in general education: A program evaluation of eight schools. Remedial and Special Education, 27, 77-94. doi: $10.1177 / 07419325060270020601$

Independent t-test using SPSS Statistics. (2016). Statistics.laerd.com. Retrieved from: https://statistics.laerd.com/spss-tutorials/independent-t-test-using-spssstatistics.php

Individuals with Disabilities Education Act, 20 U.S.C. § 1400 (2004)

Kniveton, Bromley. (2004). A Study of Perceptions that Significant Others Hold of the Inclusion of Children with Difficulties in Mainstream Classes. Educational Studies 30 (3) 331-343 Retrieved from: https://dspace.lboro.ac.uk/dspacejspui/bitstream/2134/2523/4/kniveton2004_1.pdf 
Kozleski, E., Pugach, M, Yinger R (2002). Preparing Teachers To Work with Students with Disabilities: Possibilities and Challenges for Special and General Teacher Education. Washington DC, AACTE Publications. Retrieved from: http://eric.ed.gov/?id=ED468743

Lehman, A, O'Rourke, N, Hatcher, L, Stepanski, E (2013). JMP for Basic Univariate and Multivariate Statistics: Methods for Researchers and Scientists, Second Edition. Cary, NC: SAS Institute Inc. Retrieved from http://support.sas.com/publishing/pubcat/chaps/59814.pdf

Martin, E. W., Martin, R., \& Terman, D. (1996). The Legislative and Litigation History of Special Education. The Future of Children, 6(1), 25. doi:10.2307/1602492

Marzano, R. J. (2003). Classroom strategies that work: research-based strategies for every teacher. Alexandria, VA: Association for Supervision and Curriculum Development.

Maslow, A. H. (1943). A Theory of Human Motivation. Originally Published in Psychological Review, 50, 370-396. [internet resource developed by Green, C.] Retrieved from: psychclassics.yorku.ca/Maslow/motivation.htm

Mastropieri, M. A., \& Scruggs, T. E. (2000). The inclusive classroom. Strategies for effective instruction. Upper Saddle River, NJ: Merrill.

McLaughlin, M. J. and Rhim, L. M. 2007. Accountability frameworks and children with disabilities: A test of assumptions about improving public education for all Students International Journal of Disability, Development and Education, 54: 2549. Retrieved from: http://dx.doi.org/10.1080/10349120601149698 
Missouri Protection and Legal Rights Advocacy Services. (2004). Legal Rights Handbook. Retrieved from: http://www.moadvocacy.org/Manuals/LegalRights/Education.pdf

Missouri Department of Elementary and Secondary Education (2015). End of Course Assessments Technical Report 2014-2015. Retrieved from: https://dese.mo.gov/sites/default/files/asmt-tac-eoc-tech-report-1415.pdf

Missouri Department of Elementary and Secondary Education (2017). End of Course Retrieved from: https://dese.mo.gov/college-career-readiness/assessment/endcourse

Missouri Department of Elementary and Secondary Education (2016). Missouri Board of Education Weighs in on Every Student Succeeds Act. Retrieved from: https://dese.mo.gov/communications/news-releases/missouri-board-educationweighs-every-student-succeeds-act

Missouri Department of Elementary and Secondary Education (2013). Missouri State Plan for Special Education Regulations Implementing Part B of the Individuals with Disabilities Education Act. Retrieved from: https://dese.mo.gov/sites/default/files/StatePlanPartB2014.pdf

Missouri Department of Elementary and Secondary Education (2016). Quick Facts, District and School Information. Retrieved from: https://mcds.dese.mo.gov/quickfacts/Pages/default.aspx Missouri Legal Aid, (2006). Special Education Legal Requirements: IDEIA Retrieved from: http://www.lsmo.org/node/513/special-education-legal-requirementsideia\#WhoHasRights 
Missouri Protection and Legal Rights Advocacy Services. (2004). Legal Rights Handbook. Retrieved from: http://www.moadvocacy.org/Manuals/LegalRights/Education.pdf

Mitra, D. L. (2003). Student voice in school reform: Reframing student-teacher relationships. McGill Journal of Education, 38(2), 289-304.

Murawski, W. W, \& Swanson, H. L. (2001). A Meta-Analysis of Co-Teaching Research: Where Are the Data?. Remedial and Special Education 22: 258-267. doi:10.1177/074193250102200501 Retrieved from: http://www.2teachllc.com/murawski\%20Swanson\%202001.pdf

No Child Left Behind (NCLB) Act of 2001, Pub. L. No. 107-110, § 115, Stat. 1425 (2002).

Ozgurzan. A brief introduction to motivation theory. [Web log]. Retrieved from: http://ozgurzan.com/management/management-theories/theories-aboutmotivation/

One-way MANOVA in SPSS Statistics - Step-by-step procedure with screenshots | Laerd Statistics. (2016). Statistics.laerd.com. Retrieved 4 September 2016, from https://statistics.laerd.com/spss-tutorials/one-way-manova-using-spssstatistics.php

P.A.R.C. v. Pennsylvania, 334 F. Supp. 1257 (E.D. PA 1972).

Pajares, F., \& Schunk, D. (2001). The development of academic self-efficacy. Development of achievement motivation. United States. 
Pearson Inc. (2016). Missouri Educator Gateway Assessments: Missouri Certification Fields and Content Assessments. Retrieved from: http://www.mo.nesinc.com/Content/Docs/MEGA_Requirements.pdf

Pianta, R. C. (1999). Enhancing relationships between children and teachers. Washington, DC: American Psychological Association.

Pulliam, J. D., \& Van Patten, J. J. (2006). History of education in America (9th ed.). Upper Saddle River, NJ: Pearson Education.

Questions and Answers on Least Restrictive Environment (LRE) Requirements of the IDEA - Wrightslaw. (n.d.). Retrieved August 20, 2016, from http://www.wrightslaw.com/info/lre.osers.memo.idea.htm

Rayner, S. (2007). Managing special and inclusive education. London: Sage.

Rawls, J. (1971). A Theory of Justice. Cambridge MA: Harvard University Press. Retrieved from: https://books.google.com/books?id=vcVEPc30ut0C\&pg=PA9\&source=gbs_toc_r $\& \mathrm{cad}=3 \# \mathrm{v}=$ onepage $\& \mathrm{q} \& \mathrm{f}=$ false

Rebhorn, T., Smith, A. (2008). Module 15: LRE Decision Making. Retrieved from: http://www.parentcenterhub.org/repository/partb-module15/

Ryan, R. \& Connell, J.P. (1989). Perceived locus of causality and internalization: Examining reasons for acting in two domains. Journal of Personality and Social Psychology, 57, 749-761. http://www.teachstone.org/about-the-class/

Sailor, W. (2009). Making RTI work: How smart schools are reforming education through schoolwide Response-to-Intervention. San Francisco: Jossey-Bass. 
Sailor, W. \& Roger, B. (2005). Rethinking inclusion: Schoolwide applications. Phi Delta Kappan, 86 (7)503-509.

Sanzo, K., Clayton, J., \& Sherman, W. (2011). Students with special needs, reading education, and principals: Bridging the divide through instructional leadership. International Journal of Educational Leadership Preparation. 6 (1), Retrieved from http://www.ncpeapublications.org/volume-6-number-1.html

State Plan for Special Education - Part B. (2014). Retrieved June 3, 2015, from http://dese.mo.gov/governmental-affairs/dese-administrative-rules/incorporatedreference-materials/IDEAPartB-2014

Taylor, J. (2014). Statistical Soup: ANOVA, ANCOVA, MANOVA, \& MANCOVA. [weblog post]. Retrieved from http://www.statsmakemecry.com/smmctheblog/stats-soup-anova-ancova-manovamancova

Theoharis, G. (2010). Sustaining social justice: Strategies urban principals develop to advance justice and equity while facing resistance. International Journal of Urban Educational Leadership, 4(1), 92-100. doi: 10.1177/0013161X06293717

Thomas, S. B., \& Rapport, M. J. K. (1998). The least restrictive environment: Understanding the directions of the courts. The Journal of Special Education, 32(2), 66- 78 . 
Topping, K., Maloney, S. (2005). Inclusive Education; the ideals and the practice. In The RoutledgeFalmer Reader in Inclusive Education (pp. 17 - 28). Retrieved from https://books.google.com/books?id=uarEv4G3VYC\&pg=PR5\&dq=Rawls+social + justice + theory + to + support + coteaching $\& 1 \mathrm{r}=\&$ source $=$ gbs_selected_pages $\&$ cad $=$ $2 \# \mathrm{v}=$ onepage $\& \mathrm{q} \& \mathrm{f}=\mathrm{fals}$

Trochim, W. (2006). Inferential Statistics. In Research Methods Knowledge Base. Retrieved from: http://socialresearchmethods.net/kb/statinf.php

U.S. Department of Education, National Center for Education Statistics. (2016). The Digest of Education Statistics, 2014 (NCES 2016-006), Table 204.60. Retrieved from: http://nces.ed.gov/fastfacts/display.asp?id=59

U. S. Department of Education. (1997). Eighteenth annual report to congress on the implementation of the Individuals with Disabilities Education Act. Washington, DC: U.S. Government Printing Office.

U.S. Department of Education. (2017). Every Child Succeeds Act (ESSA). Retrieved from: https://www.ed.gov/esea

U. S. Department of Education. (2002). Twenty-third annual report to congress on the implementation of the Individuals with Disabilities Education Act. Washington, DC: U. S. Government Printing Office.

U. S. Department of Education (2007). Twenty-Five Years of Progress in Educating Children With Disabilities. Archived: A 25 Year History of the IDEA. Retrieved from: http://www2.ed.gov/policy/speced/leg/idea/history.html 
U. S. Department of Education (2007). Questions and Answers on Highly Qualified Teachers Serving Children with Disabilities. $Q \& A$. Retrieved from: http://idea.ed.gov/explore/view/p/,root,dynamic,QaCorner,2,

U.S. Department of Education, Office of Special Education and Rehabilitation Services (1994). Questions and Answers on LRE Requirements of the IDEA. Wrightslaw Topics: LRE/Inclusion. Retrieved from: http://www.wrightslaw.com/info/lre.osers.memo.idea.htm

US Department of Health and Human Services Office of Research Integrity (nd). Model 2: Research Design. Retrieved from: http://ori.hhs.gov/content/module-2-research-design

Walsh, James. (2012). Co-Teaching as a School System Strategy for Continuous Improvement Preventing School Failure. Alternative Education for Children and Youth, 56:1, 290 36, doi: http://dx.doi.org/10.1080/1045988x.2011.555792

Will, M. (1986). Educating students with learning problems-A shared responsibility. Exceptional Children, 24, 67-74.

Wischnowski, M. W., Salmon, S. J., \& Eaton, K. (2004). Evaluating Co-teaching as a Means for Successful Inclusion of Students with Disabilities in a Rural District. Rural Special Education Quarterly, 23(3), 3-14.

Young, I.M. 2000. Inclusion and democracy. Oxford: Oxford University Press. Zaretsky, L. (2005). From practice to theory: Inclusive models require inclusive theories. American Secondary Education, 33(3), 65-86. 
Appendix A

\begin{tabular}{|c|c|c|c|c|}
\hline Course & Grade & EOC & Level & Task \\
\hline Biology & 73 & 68 & Below & *Sem Grade \\
\hline Biology & 71 & 56 & Below & *Sem Grade \\
\hline Biology & 72 & 52 & Below & *Sem Grade \\
\hline Biology & 75 & 86 & Prof & *Sem Grade \\
\hline Biology & 67 & 65 & Basic & *Sem Grade \\
\hline Biology & 77 & 70 & Basic & *Sem Grade \\
\hline Biology & 65 & 61 & Basic & *Sem Grade \\
\hline Biology & 70 & 61 & Basic & *Sem Grade \\
\hline Biology & 78 & 70 & Basic & *Sem Grade \\
\hline Biology & 78 & 61 & Basic & *Sem Grade \\
\hline Biology & 68 & 74 & Basic & *Sem Grade \\
\hline Biology & 64 & 68 & Basic & *Sem Grade \\
\hline Biology & 78 & 70 & Basic & *Sem Grade \\
\hline Biology & 71 & 63 & Basic & *Sem Grade \\
\hline Biology & 70 & 86 & Prof & *Sem Grade \\
\hline Biology & 81 & 59 & Below & *Sem Grade \\
\hline Biology & 72 & 68 & Basic & *Sem Grade \\
\hline Biology & 67 & 70 & Basic & *Sem Grade \\
\hline Biology & 63 & 61 & Basic & *Sem Grade \\
\hline Biology & 78 & 56 & Below & *Sem Grade \\
\hline Biology & 67 & 69 & Basic & *Sem Grade \\
\hline Biology & 68 & 59 & Below & *Sem Grade \\
\hline Biology & 78 & 73 & Basic & *Sem Grade \\
\hline Biology & 84 & 77 & Basic & *Sem Grade \\
\hline Biology & 69 & 65 & Basic & *Sem Grade \\
\hline Biology & 76 & 65 & Basic & *Sem Grade \\
\hline Biology & 69 & 63 & Basic & *Sem Grade \\
\hline Biology & 78 & 53 & Below & *Sem Grade \\
\hline Biology & 68 & 77 & Basic & *Sem Grade \\
\hline Biology & 67 & 71 & Basic & *Sem Grade \\
\hline Biology & 77 & 59 & Below & *Sem Grade \\
\hline Biology & 67 & 65 & Basic & *Sem Grade \\
\hline Biology & 80 & 70 & Basic & *Sem Grade \\
\hline Biology & 78 & 75 & Basic & *Sem Grade \\
\hline Biology & 71 & 59 & Below & *Sem Grade \\
\hline Biology & 66 & 45 & Below & *Sem Grade \\
\hline Biology & 65 & 61 & Basic & *Sem Grade \\
\hline
\end{tabular}




\begin{tabular}{|l|l|l|l|l|} 
Biology & 81 & 77 & Basic & *Sem Grade \\
\hline Biology & 75 & 56 & Below & *Sem Grade \\
\hline Biology & 71 & 64 & Basic & *Sem Grade \\
\hline Biology & 61 & 71 & Basic & *Sem Grade \\
\hline Biology & 72 & 75 & Basic & *Sem Grade \\
\hline Biology & 57 & 52 & Below & *Sem Grade \\
\hline Biology & 63 & 53 & Below & *Sem Grade \\
\hline Biology & 77 & 59 & Below & *Sem Grade \\
\hline Biology & 72 & 74 & Basic & *Sem Grade \\
\hline Biology & 78 & 77 & Basic & *Sem Grade \\
\hline
\end{tabular}


Appendix B

\begin{tabular}{|c|c|c|c|c|}
\hline Course & Course & EOC & Level & Task \\
\hline Eng II & 82 & 71 & Basic & *Sem Grade \\
\hline Eng II & 86 & 86 & Prof & *Sem Grade \\
\hline Eng II & 81 & 50 & Below & *Sem Grade \\
\hline Eng II & 74 & 77 & Prof & *Sem Grade \\
\hline Eng II & 48 & 77 & Prof & *Sem Grade \\
\hline Eng II & 78 & 65 & Basic & *Sem Grade \\
\hline Eng II & 82 & 92 & Adv & *Sem Grade \\
\hline Eng II & 71 & 60 & Basic & *Sem Grade \\
\hline Eng II & 73 & 71 & Basic & *Sem Grade \\
\hline Eng II & 64 & 71 & Basic & *Sem Grade \\
\hline Eng II & 86 & 71 & Basic & *Sem Grade \\
\hline Eng II & 33 & 47 & Below & *Sem Grade \\
\hline Eng II & 76 & 73 & Basic & *Sem Grade \\
\hline Eng II & 91 & 92 & $\mathrm{Adv}$ & *Sem Grade \\
\hline Eng II & 68 & 65 & Basic & *Sem Grade \\
\hline Eng II & 69 & 69 & Basic & *Sem Grade \\
\hline Eng II & 81 & 71 & Basic & *Sem Grade \\
\hline Eng II & 69 & 73 & Basic & *Sem Grade \\
\hline Eng II & 84 & 63 & Basic & *Sem Grade \\
\hline Eng II & 82 & 71 & Basic & *Sem Grade \\
\hline Eng II & 76 & 86 & Prof & *Sem Grade \\
\hline Eng II & 73 & 71 & Basic & *Sem Grade \\
\hline Eng II & 80 & 71 & Basic & *Sem Grade \\
\hline Eng II & 77 & 50 & Below & *Sem Grade \\
\hline Eng II & 70 & 74 & Basic & *Sem Grade \\
\hline Eng II & 78 & 50 & Below & *Sem Grade \\
\hline Eng II & 76 & 58 & Below & *Sem Grade \\
\hline Eng II & 70 & 65 & Basic & *Sem Grade \\
\hline Eng II & 68 & 53 & Below & *Sem Grade \\
\hline Eng II & 88 & 77 & Basic & *Sem Grade \\
\hline Eng II & 82 & 53 & Below & *Sem Grade \\
\hline Eng II & 68 & 50 & Below & *Sem Grade \\
\hline Eng II & 70 & 56 & Below & *Sem Grade \\
\hline
\end{tabular}


Appendix C

\begin{tabular}{|c|c|c|c|c|}
\hline Course & $\begin{array}{l}\text { Course } \\
\text { Grade }\end{array}$ & EOC Grade & EOC Level & Task \\
\hline Gov US, MO & 77 & 85 & Basic & *Sem Grade \\
\hline Gov US, MO & 65 & 85 & Below & *Sem Grade \\
\hline Gov US, MO & 88 & 88 & Below & *Sem Grade \\
\hline Gov US, MO & 75 & 89 & Basic & *Sem Grade \\
\hline Gov US, MO & 86 & 88 & Prof & *Sem Grade \\
\hline Gov US, MO & 83 & 91 & Basic & *Sem Grade \\
\hline Gov US, MO & 74 & 84 & Prof & *Sem Grade \\
\hline Gov US, MO & 79 & 89 & Basic & *Sem Grade \\
\hline Gov US, MO & 83 & 83 & Prof & *Sem Grade \\
\hline Gov US, MO & 83 & 83 & Below & *Sem Grade \\
\hline Gov US, MO & 82 & 85 & Below & *Sem Grade \\
\hline Gov US, MO & 72 & 89 & Below & *Sem Grade \\
\hline Gov US, MO & 54 & 88 & Basic & *Sem Grade \\
\hline Gov US, MO & 83 & 87 & Basic & *Sem Grade \\
\hline Gov US, MO & 82 & 87 & Basic & *Sem Grade \\
\hline Gov US, MO & 83 & 88 & Basic & *Sem Grade \\
\hline Gov US, MO & 88 & 89 & Basic & *Sem Grade \\
\hline Gov US, MO & 77 & 82 & Prof & *Sem Grade \\
\hline Gov US, MO & 88 & 87 & Below & *Sem Grade \\
\hline Gov US, MO & 90 & 93 & Basic & *Sem Grade \\
\hline Gov US, MO & 70 & 85 & Prof & *Sem Grade \\
\hline Gov US, MO & 60 & 88 & Below & *Sem Grade \\
\hline Gov US, MO & 80 & 86 & Prof & *Sem Grade \\
\hline Gov US, MO & 89 & 84 & Basic & *Sem Grade \\
\hline Gov US, MO & 73 & 83 & Below & *Sem Grade \\
\hline Gov US, MO & 78 & 85 & Below & *Sem Grade \\
\hline Gov US, MO & 73 & 83 & Below & *Sem Grade \\
\hline Gov US, MO & 79 & 86 & Below & *Sem Grade \\
\hline Gov US, MO & 82 & 84 & Basic & *Sem Grade \\
\hline Gov US, MO & 74 & 87 & Below & *Sem Grade \\
\hline Gov US, MO & 87 & 83 & Basic & *Sem Grade \\
\hline Gov US, MO & 75 & 65 & Below & *Sem Grade \\
\hline Gov US, MO & 75 & 67 & Below & *Sem Grade \\
\hline Gov US, MO & 76 & 54 & Below & *Sem Grade \\
\hline Gov US, MO & 73 & 67 & Below & *Sem Grade \\
\hline Gov US, MO & 81 & 74 & Below & *Sem Grade \\
\hline Gov US, MO & 67 & 67 & Below & *Sem Grade \\
\hline Gov US, MO & 74 & 65 & Below & *Sem Grade \\
\hline
\end{tabular}




\begin{tabular}{|l|l|l|l|l|} 
Gov US, MO & 75 & 65 & Below & *Sem Grade \\
\hline Gov US, MO & 72 & 61 & Below & *Sem Grade \\
\hline Gov US, MO & 66 & 59 & Below & *Sem Grade \\
\hline Gov US, MO & 67 & 74 & Below & *Sem Grade \\
\hline Gov US, MO & 70 & 75 & Below & *Sem Grade \\
\hline Gov US, MO & 68 & 59 & Below & *Sem Grade \\
\hline Gov US, MO & 79 & 67 & Below & *Sem Grade \\
\hline Gov US, MO & 72 & 63 & Below & *Sem Grade \\
\hline Gov US, MO & 73 & 61 & Below & *Sem Grade \\
\hline
\end{tabular}




\section{VITA}

Karin McGrath holds a Bachelor of Science in Child and Family Development from Truman State University, a Master of Arts in Human Service Agency Management from Lindenwood University, a Master of Education from Missouri Baptist University, and an Educational Specialist from the University of Missouri, Columbia.

Prior entering the field of education, Karin worked with youth development and non-profit agencies in a variety of roles, including fundraising, support programming for children and families affected by childhood cancer and related illnesses, grief support programs, and summer camp experiences for at-risk youth. Additionally, she has held certification and worked as a Child Life Specialist, a field which focuses on socialemotional components of health care and hospitalization for children.

She currently teaches within the special services department at the upper school of Westminster Christian Academy in Town and Country Missouri. Previously she taught at Northwest High School in Cedar Hill, Missouri, and Affton-Lindbergh Early Childhood in St. Louis, Missouri. During her teaching profession, in addition to her emphasis in special education and individual learning needs, she has worked extensively with character education, behavioral supports, student leadership, and professional development for faculty and staff. 